\title{
Dalechampia (Euphorbiaceae, Acalyphoideae): synopsis of species from Northeast Brazil
}

\author{
Rafaela Alves Pereira-Silva ${ }^{1 \oplus}$, Beatriz Rayrana de Araújo Gama ${ }^{1}$, Sarah Maria Athiê-Souza ${ }^{1}$, \\ André Laurênio de Melo ${ }^{2}$, Margareth Ferreira de Sales ${ }^{1(\mathbb{D}}$ \\ ${ }^{1}$ Universidade Federal Rural de Pernambuco, Rua Dom Manuel de Medeiros s/n, Dois Irmãos, 52171-900, \\ Recife, PE, Brasil \\ ${ }^{2}$ Universidade Federal Rural de Pernambuco, Unidade Acadêmica de Serra Talhada, 56909-535, Serra \\ Talhada, PE, Brasil. \\ *Corresponding author: RafaelaA.Pereira-Silva,e-mail: rafaela.news@hotmail.com
}

PEREIRA-SILVA, R.A., GAMA, B.R.A., ATHIÊ-SOUZA, S.M., MELO, A.L., SALES, M. F. Dalechampia (Euphorbiaceae, Acalyphoideae): synopsis of species from Northeast Brazil. Biota Neotropica 20(2): e20190805. https://doi.org/10.1590/1676-0611-BN-2019-0805.

\begin{abstract}
A synopsis of the Dalechampia from Northeastern Brazil is presented here, with discussions of their diagnostic features. The study was based on the analysis of herbarium material (including historical collections and types), specimens collected in the field, and bibliographic documentation. Twenty-eight species distributed among five sections were recognized, 19 of them endemic to Brazil. Most of the species are found in Caatinga and Atlantic Forest vegetation. A key for species identifications is provided, together with illustrations, and information on their geographic distributions and conservation statuses.
\end{abstract}

Keywords: Dalechampiinae; Flora; Plukenetieae; Taxonomy.

\section{Dalechampia (Euphorbiaceae, Acalyphoideae): sinopse das espécies do Nordeste do Brasil}

Resumo: Uma sinopse da Dalechampia do Nordeste do Brasil é apresentada aqui com uma discussão sobre as características diagnósticas. O estudo foi baseado na análise de materiais de herbário (incluindo coleções históricas e tipos), espécimes coletados durante o trabalho de campo, além de documentação bibliográfica. Vinte e oito espécies distribuídas em cinco seções foram reconhecidas, 19 delas endêmicas no Brasil. A maioria das espécies está distribuída na Caatinga e na Mata Atlântica. Uma chave para a identificação de espécies é fornecida juntamente com ilustrações, informações sobre as distribuições geográficas e status de conservação.

Palavras-chave: Dalechampiinae; Flora; Plukenetieae; Taxonomia. 


\section{Introduction}

Dalechampia L. comprises approximately 130 species distributed pantropically, 90 of which are found in the tropical Americas, with its center of diversity being in South America (Armbruster et al. 1993). Brazil stands out for its diversity of species, with 72 taxa widely disseminated throughout the country in different vegetation types (Maya-Lastra et al. 2015). Southeastern Brazil holds $47.2 \%$ of the country's Dalechampia diversity (34 spp.), although Bahia State (located in the northeastern region) has the largest number of species (23 spp.), followed by the states of Minas Gerais and São Paulo, with 20 species each (both in the southeastern region), and Amazonas State (northern region) with 19 species. Neotropical savanna (Cerrado) and Atlantic Forest regions hold the largest numbers of genera (32 and 31 respectively), while the northeastern region holds 29 species, representing $39 \%$ of the species richness of the country (Flora do Brasil 2020, under construction). The Caatinga and Atlantic Forest phytogeographic domains concentrate the highest representivity of Dalechampia (Flora do Brasil 2020, under construction).

The inflorescences and flowers of Dalechampia provide the best morphological features for characterizing the genus. The inflorescence is a pseudanthium, distinguishable from the other genera of Euphorbiaceae by having two large involucral bracts varying in color from whitish, yellowish-greenish, pink, to magenta; those bracts can be entire, 3 lobed, or deeply 3-5-lobed, and are inserted below a pistillate cymule of 1-3 flowers, with staminate pleiochasium that can range from 4 to almost 50 flowers (Webster \& Armbruster 1991 Armbruster, 2017). Most species have resiniferous secretory glands, or emit volatile aromatic compounds from the staminate subflorescence (Armbruster \& Webster 1979, Webster \& Armbruster, 1991). From a vegetative point of view, they are mostly herbaceous and climbing plants. Subshrub species are occasionally encountered, but almost exclusively in central-western Brazil (Pax \& Hoffmann 1919, Webster \& Armbruster 1991, Flora do Brasil 2020, under construction). The leaves can be extremely variable within a single species, and even on the same individual (Webster \& Armbruster 1991).

The treatment by Webster \& Armbruster (1991), which included the South American species of Dalechampia, is still the most recent and most complete. Although those authors did not provide descriptions of the species, they detailed morphological aspects and rearranged the sections and subsections. Some floristic studies involving Dalechampia (or part of the genus) have been conducted in Brazil (Alves 1998, Sales et al. 1998, Maya-Lastra 2015, Barbosa et al. 2006, Rodrigues 2007, Sátiro \& Roque 2008, Pereira-Silva et al. 2015, Pereira-Silva et al. 2016, Souza et al. 2016), although they have been limited in scope and have not covered the entire northeastern region. Dalechampia diversity in northeastern Brazil is relevant, being the third highest richest region of the country (28 spp.), behind only the southeast (34 spp.) and central-west (30 spp.). Additionally, the northeastern region holds three of the four ecosystems with high representivities for the genus (Atlantic Forest, Cerrado, and Caatinga) (Flora do Brasil 2020, under construction). Bahia, the state with the highest recorded number of Dalechampia species in Brazil, is inserted in that region. At least six new occurences (D. fernandesii Webster, D. armbrusteri Webster, $D$. viridissima Webster, D. allemi Webster, D. purpurata Cordeiro, and $D$. erythrostyla R. A. Pereira-Silva \& A. L. Melo) have been discovered in Bahia in recent decades, as well as D. erythrostyla in Pernambuco
State, also in the northeast (Flora do Brasil 2020, under construction). As such, the present work updates the geographical distribution of Dalechampia in northeastern Brazil, reports three new occurrences for that country, and provides a key to the identification, with illustrations and comments of all of its species.

\section{Materials and Methods}

Northeastern Brazil comprises nine states (Alagoas, Bahia, Ceará, Maranhão, Paraíba, Pernambuco, Piauí, Rio Grande do Norte, and Sergipe), and covers an area of more than $1,500,000 \mathrm{~km}^{2}$, equivalent to approximately $20 \%$ of the area the country (IBGE 2004).

The main geological features found in the northeastern region are Great Depressions (e.g., the mid-São Francisco depression), interspersed with plateaus and other mountain ranges with elevations often above $800 \mathrm{~m}$ a.s.l. (e.g., Chapada do Araripe, Chapada do Apodi, and Chapada Diamantina). The phytophysiognomies there reflect the different environmental conditions in those distinct geomorphological regions - being principally Caatinga (a low, deciduous, thorny vegetation), Cerrado (neotropical savanna, characterized by low woody and herbaceous plants, and small trees having thick bark), and Atlantic Forest (characterized by tall perennial and broad-leaved plants) (Queiroz 2009).

The regional climate in northeastern Brazil is semiarid (BSh), with mean annual temperatures between 23 and $27^{\circ} \mathrm{C}$, mean annual rainfall levels of less than $800 \mathrm{~mm}$, and relative humidity of 50\% (EMBRAPA 1993). The most frequently occurring soils in the region are: Argisols, Latosols, Neosols, Litholic, Quartzeneic Neosols, Planosols, and Vertisols (Cunha et al. 2010).

Periodic field excursions were undertaken since 2015 until 2018 to observe natural populations and make botanical collections, following the methodology described by Mori et al. (1989). The collected materials, after processing, were deposited in the Professor Vasconcelos Sobrinho Herbarium (PEUFR) of the Federal Rural University of Pernambuco.

The identifications of the taxa were based mainly on Webster \& Armbruster (1991). Exsiccates from the following herbaria were examined to analyze intraspecific morphological variations: ASE, BHCB, CEN, CEPEC, CESJ, DAV, ESA, FURB, G, HBR, HRCB, HST, HUEFS, HVASF, IAN, IBGE, INPA, IPA, K, M, MAC, MBML, NY, P, PEUFR, R, RB, S, SJRP, SP, SPF, TEPB, UB, UCR, UEC, UPCB, W (acronyms according to Thiers 2017). The standardization of vegetative and reproductive structural terminology was based on Radford (1974) and Webster \& Armbruster (1991). Comments on geographic distributions, habitats, and phenological data were based on field collections, information available in the literature, and exsiccate labels.

Map with the geographic distributions of the species was prepared using QGIS ${ }^{\circledR} 2.18$ software, based on the geographic coordinates provided on the herbarium labels (Figure 1). When geographical coordinates were not noted on the those labels, georeferencing was based on the GeoLoc tool of the speciesLink network (http://splink. cria.org.br/tools).

Conservation status assessments were primarily based on EOO (the extent of occurrence) and AOO (area of occupancy), using the Geocat web tool (http://geocat.kew.org/), following Bachman et al. (2011). Conservation statuses were subsequently determined based on criterion "B1" proposed by the IUCN red list, Version 3.1 (IUCN 2001). 


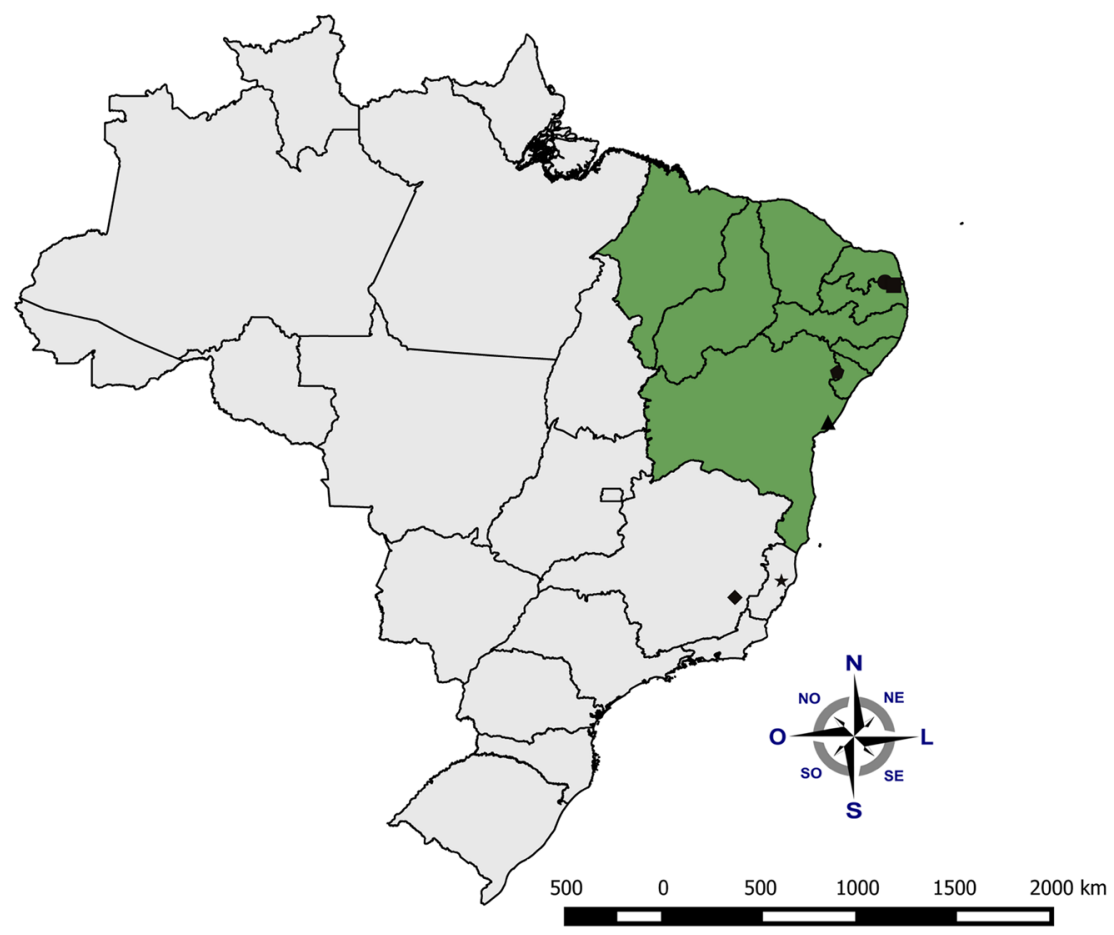

Figure 1. Map of Brazil with area of study highlighted including the distribution of the occurrences of Dalechampia .. (•) D. leandri; (•) D. subintegra; D. erythrostyla; $(\boldsymbol{\Lambda})$ D. affinis; $(\diamond)$ D. allemii; D. alata $(\star)$.

The habits of the Dalechampia plants from the Northeast, Brazil, were illustrated in Naquin (Figures 2-7). Regarding to Figures 8-10, we have opted for colorful illustration which has been useful for identification and classification of plants during centuries (Kur, 2018). It is possible to find many colorful botanical illustrations for Dalechampia since the end of $18^{\text {th }}$ and-beginning of $19^{\text {th }}$ century (see http://plantillustrations.org/species.php?id_species=319482). In that period, this style of illustrations used to be realistic representations (Hickman et al. 2017). We rescued the technique of colorful illustration reproduced by hand with adjustment of actual softwares to represent faithfully the species in the field in two dimensions, detaching the form of their pseudanthia. Some of the pseudanthia were illustrated based on photos available on the internet, these are indicated by the name of their authors; we do not intend to infringe copyright.

\section{Results and Discussion}

Dalechampia from Northeastern Brazil is represented by 28 species: D. affinis Mull. Arg., D. alata Mull. Arg., D. allemii Webster, D. arciana Baill., D. armbrusteri Webster, D. brasiliensis Lam., D. convolvuloides Lam., D. coriacea Klotzsch ex Müll. Arg., D. erythrostyla R. A. Pereira-Silva \& A. L. Melo, D. fernandesii Webster, D. ficifolia Lam., D. ilheotica Wawra, D. leandri Baill., D. linearis Baill., D. luetzelburgii Pax \& K. Hoffm., D. olfersiana Müll. Arg., D. peckoltiana Müll. Arg., D. pentaphylla Lam., D. pernambucensis Baill., D. purpurata Cordeiro, D. scandens L., D. schenckiana Pax \& K.Hoffm., D. stipulacea Mull. Arg., D. subintegra Müll. Arg., D. sylvestris S. Moore, D. tiliifolia Lam., D. triphylla Lam., and D. viridissima Webster. They form a group morphologically very diverse which differ in habit, type of leaves, color of involucral bracts and shape of stylar column. Here each species is

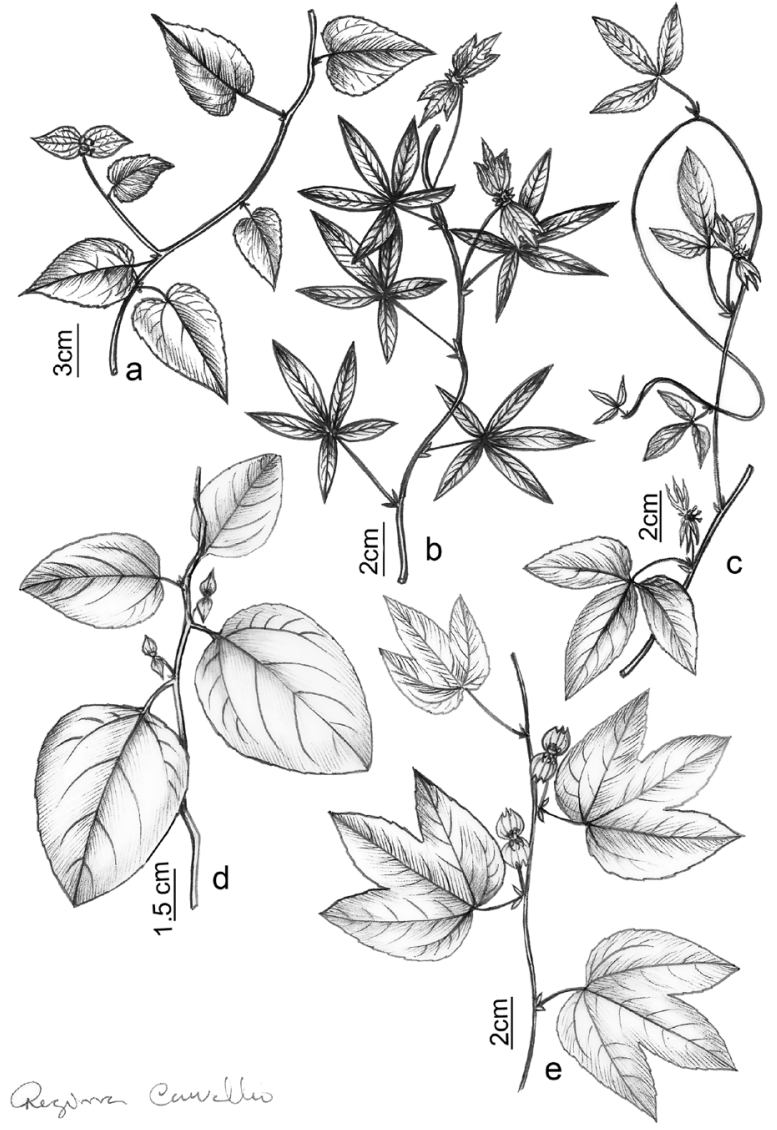

Figure 2. Habits of Dalechampia species. a. D. affinis (M.G. Silva \& R. Bahia 3591). b. D. alata (L. Kollmann et al. 2376). c. D. allemii (A.C. Allem et al. 2980). d. D. arciana (S.G. Resende \& E.G. Resende 1699). e. D. armbrusteri (Hage \& L.A.M. Silva 317). 
Pereira-Silva, RA. et al.
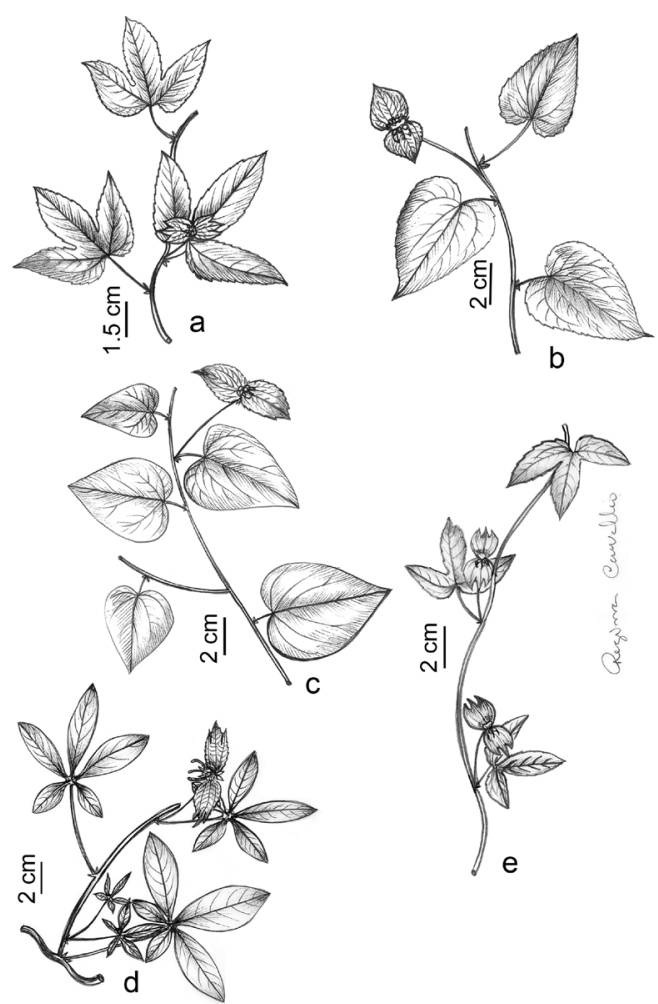

Figure 3. Habits of Dalechampia species. a. D. brasiliensis (L.R. Noblick 3565). b. D. convolvuloides (F.S. Santos Filho 007). c. D. coriacea (Allem et al. 2949). d. D. erythrostyla (R. A. Pereira-Silva \& A. L. Melo 16). e. D. fernandesii (A.M. Fernandes \& E. Matos s.n. EAC 12725).

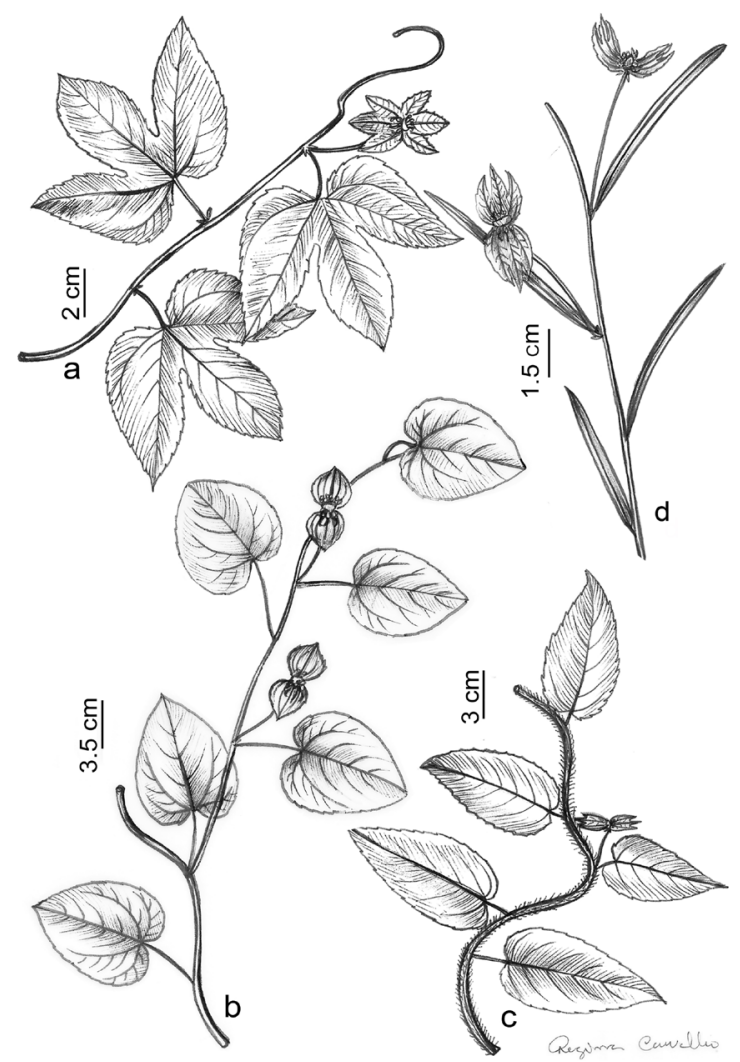

Figure 4. Habits of Dalechampia species. a. D. ficifolia (A. Korte 669). b. D. ilheotica (M.L. Guedes et al. 1198). c. D. leandri (G.L. Webster et al. 25429). d. D. linearis Baill. (T.S. Figueiras 1289).

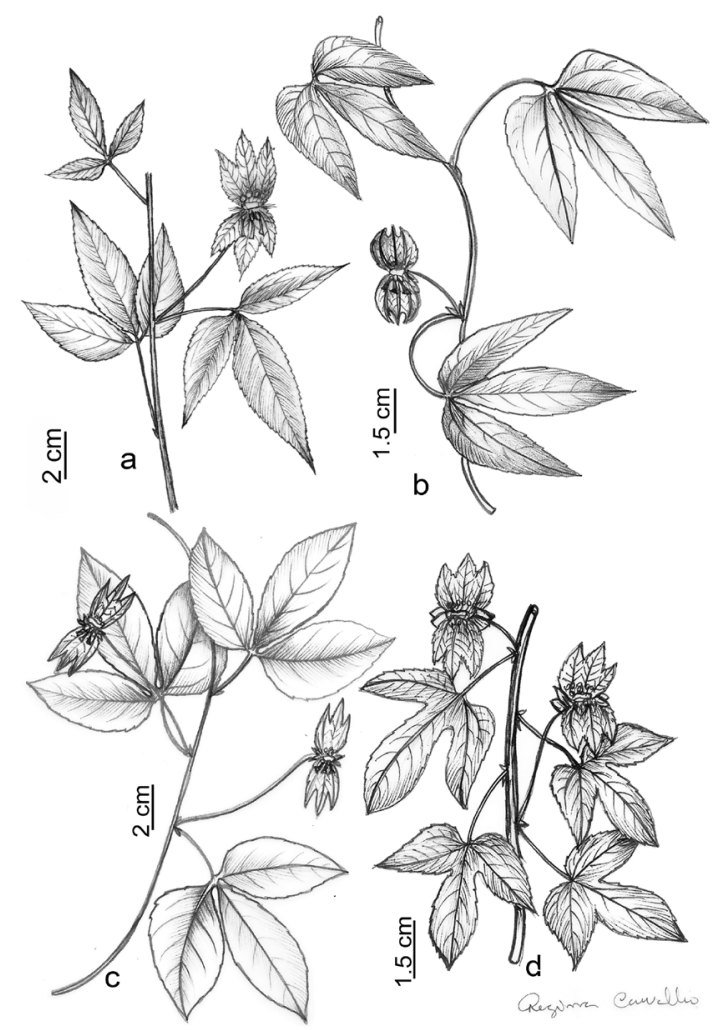

Figure 5. Habits of Dalechampia species. a. D. luetzelburgii Pax \& Hoffm. (M.R.L. Oliveira 59). b. D. olfersiana Müll. Arg. (K.R.B. Leite 212). c. D. peckoltiana (F.R. Nonato et al. 877). d. D. pernambucensis (A.S. Fernandes s.n., EAC 20877).

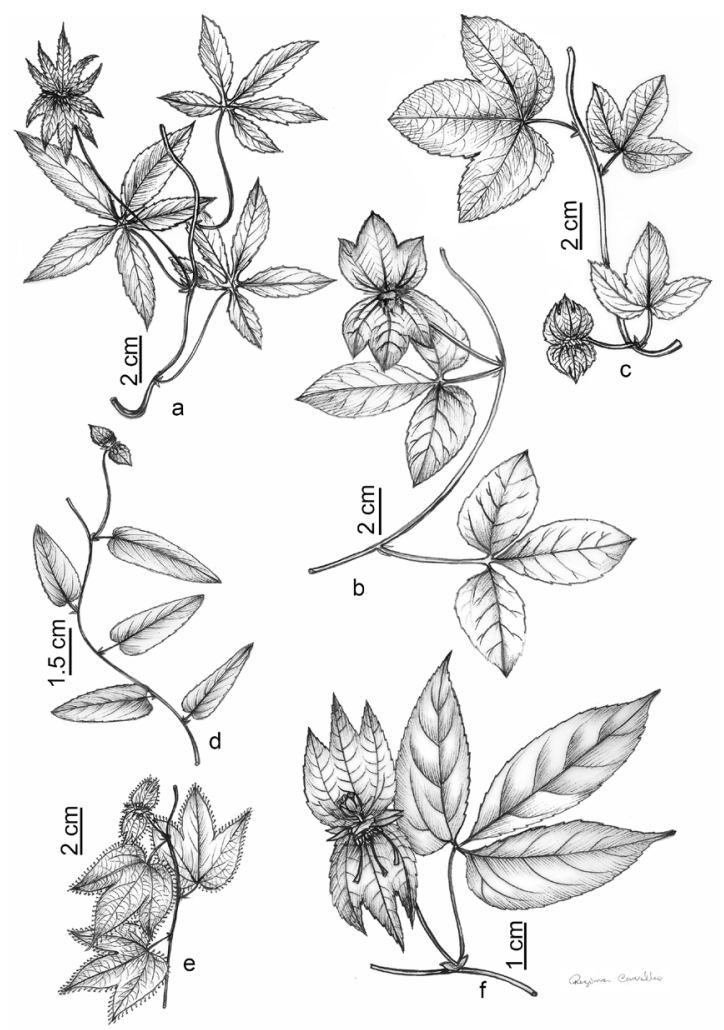

Figure 6. Habits of Dalechampia species. a. D. pentaphylla (L.P. de Queiroz et al. 9402). b.D. purpurata (B. Stannard et al. H51654). c. D. scandens L. (A.C. Allem et al. 3010). d. D. schenckiana (Pereira-Silva 37). e. D. stipulacea (A.M. Miranda et al. 2695). f. D. sylvestris (A.M Giulietti \& R. M Harley 2055). 


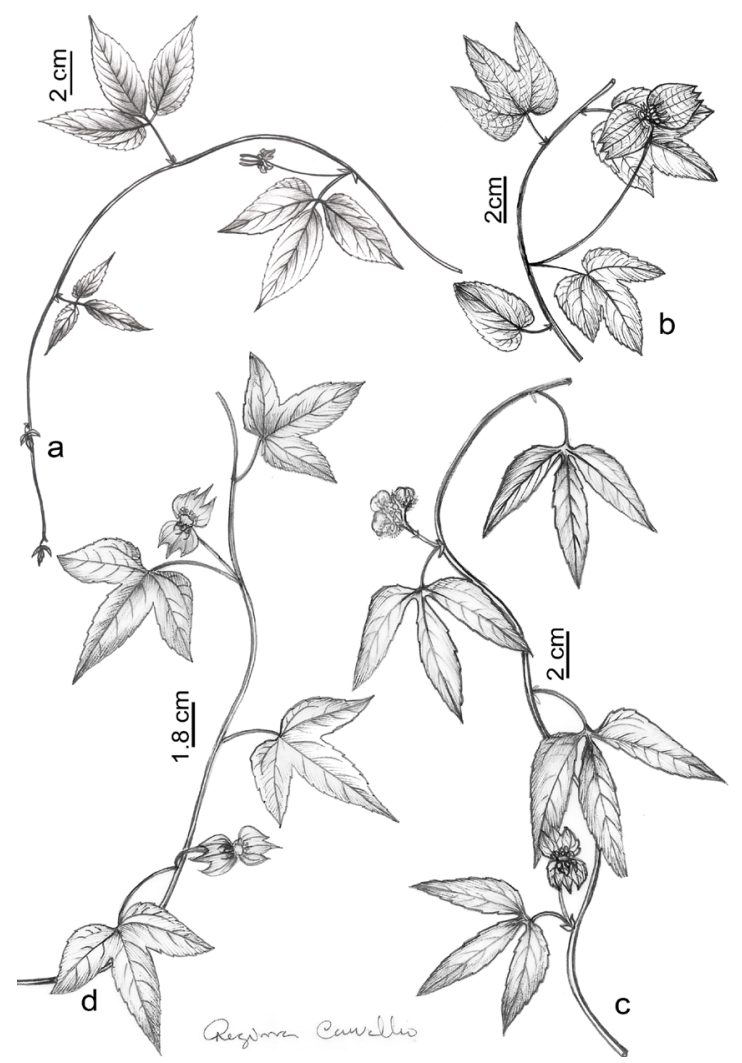

Figure 7. Habits of Dalechampia species. a. D. subintegra (P.C. Fevereiro 170). b. D. tiliifolia (M.J. Ballck et al. 1490). c. D. triphylla (K. Santos s.n., SJRP 30272). d. D. viridissima (A.M. Amorim et al. 2466).

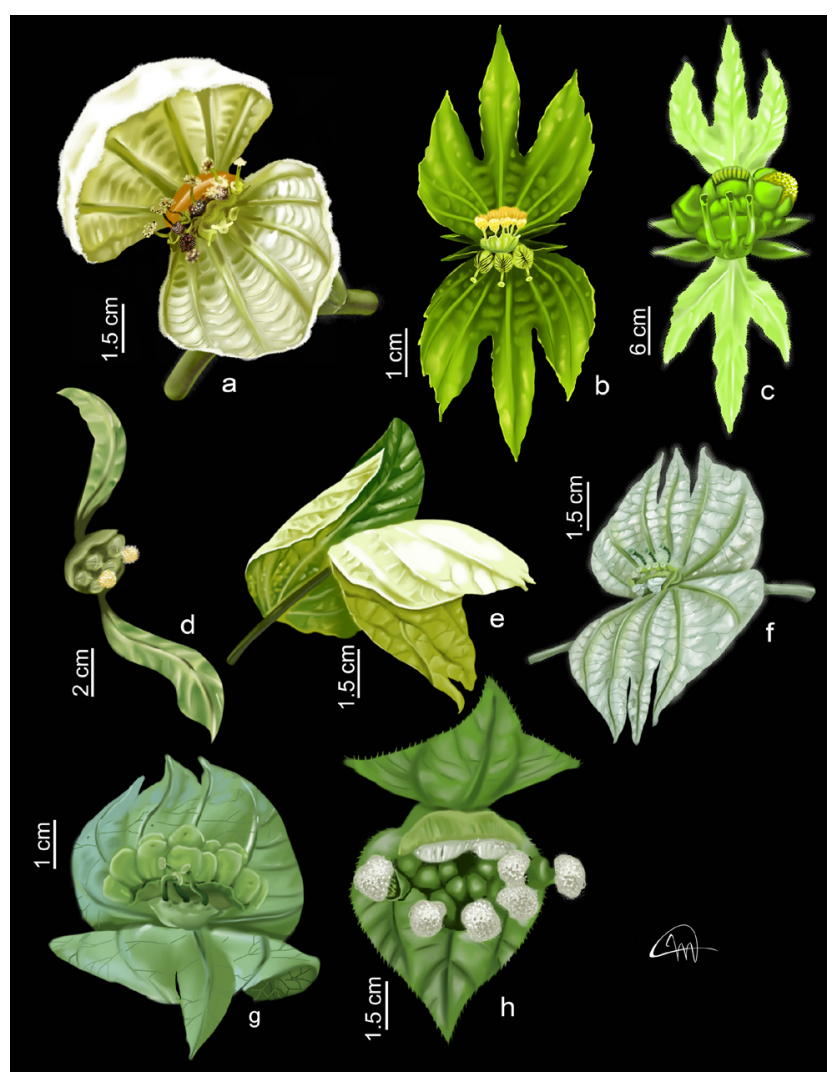

Figure 8. Pseudanthia of Dalechampia in northeastern Brazil. a. Dalechampia affinis (Photo: Alex Popovkin). b. Dalechampia alata. c. D. allemii d. D. arciana. e. D. armbrusteri. f. D. brasiliensis. g. D. convolvuloides. h. D. coriacea.

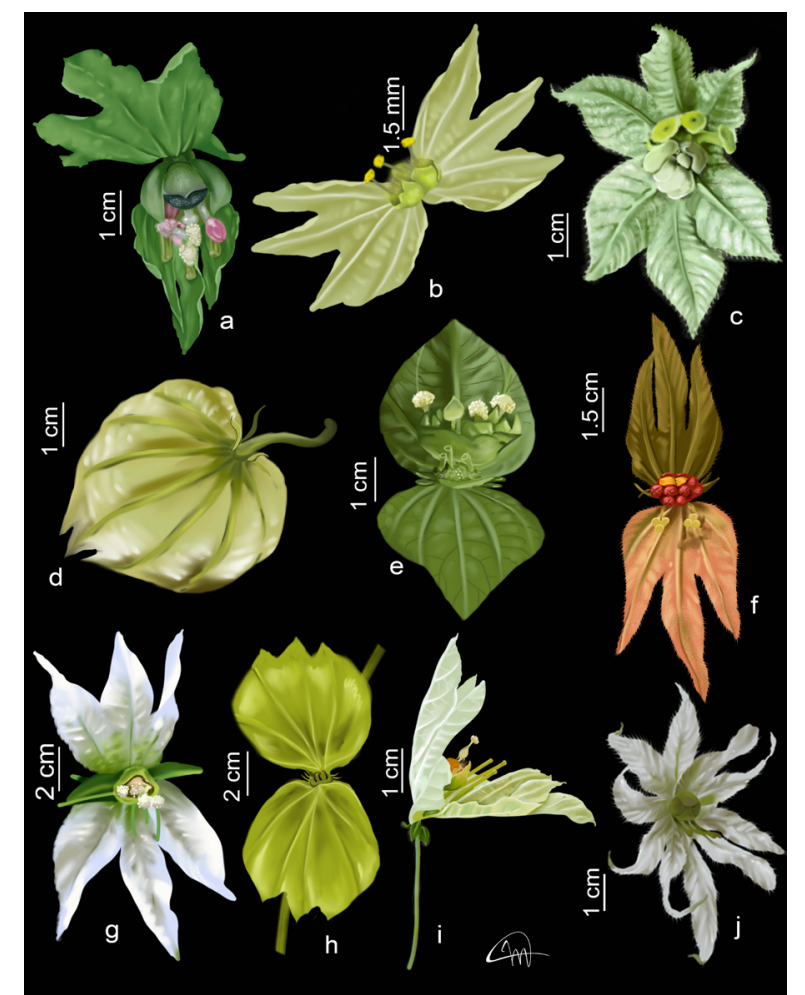

Figure 9. Pseudanthia of Dalechampia in northeastern Brazil. a. D. erythrostyla. b. D. fernandesii. c. D. ficifolia (Photo: Marcia Stefani). d. D. ilheotica. e. D. leandri. f. D. linearis (Photo: Marcelo F. Simon). g. D. luetzelburgii (Photo:Daniela Zappi). h. D. olfersiana Müll. Arg. i. D. peckoltiana (Photo: Alex Popovkin). j. D. pentaphylla (Photo: pybio.org)

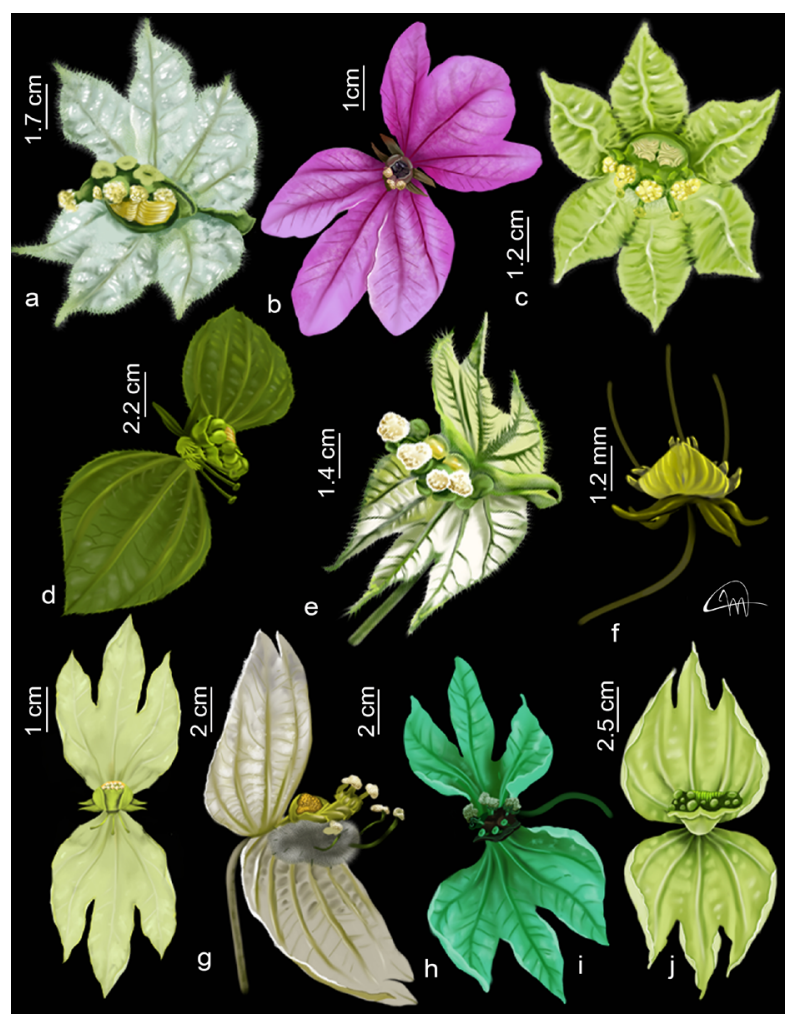

Figure 10. Pseudanthia of Dalechampia in northeastern Brazil. a. D. pernambucensis (Photo: Roberto Guerra). b. D. purpurata (Photo: Eduardo Saar). c. D. scandens (Photo: W.J. Hayden). d. D. schenckiana. e. D. stipulacea. f. D. subintegra. g. D. sylvestris. h. D. tiliifolia (Photo: Andres Hernandez). i. D. aff. triphylla (Photo: Eduardo Lozano). j. D. viridissima. 
characterized and compared with related taxa, being a great contribution for identification of more than $37 \%$ of the genus from Brazil. In addition, we present a key more complete for the group until the moment.

From those species listed, seven are new occurrences identified in this work, five in northeastern Brazil and one in the southeast (Figure 1). Where Dalechampia erythrostyla is reported here for the first time for Sergipe State, D. leandri for Paraíba State, D. pernambucensis for Piauí State, D. affinis and D. linearis for Bahia State, D. allemii for Minas Gerais (southeast) and D. alata for Espírito Santo (southeast). Among these 28 species identified in the northeastern Brazil, five of the six sections are represented (Coriaceae, Dalechampia, Dioscoreifoliae, Tiliifoliae, and Triphyllae) (Table 1).

Table 1. Species from northeastern Brazil in their respective sections.

\begin{tabular}{lc}
\hline Sections & Species \\
\hline $\begin{array}{l}\text { Coriaceae Pax \& K. } \\
\text { Hoffm }\end{array}$ & D. coriacea \\
& $\begin{array}{l}\text { D. allemii, D. armbrusteri, D. brasiliensis, } \\
\text { D. convolvuloides, D. ficifolia, D. leandri, D. } \\
\text { linearis, D. olfersiana, D. pernambucensis, } \\
\text { Dalechampia L. scandens, D. schenckiana, D. stipulacea, } \\
\text { D. triphylla, D. viridissima }\end{array}$ \\
$\begin{array}{l}\text { Dioscoreifoliae Pax } \\
\text { \& K. Hoffm. }\end{array}$ & $\begin{array}{c}\text { D. alata, D. arciana, D. erythrostyla, } \\
\text { D. luetzelburgii, D. peckoltiana, D. }\end{array}$ \\
$\begin{array}{l}\text { Tiliifoliae G. L. Webster } \\
\text { \& Armbruster }\end{array}$ & $\begin{array}{c}\text { D. affinis, D. fernandesii, D. ilheotica, D. } \\
\text { tiliifolia }\end{array}$ \\
\hline
\end{tabular}

Most of them from northeastern were observed to occur in Bahia (25 spp.), followed by Pernambuco (16 spp.) and Sergipe (9 spp.). Occurring mainly in Atlantic Forest phytophysiognomies (coastal and montane vegetations), and preferably in sunny areas (such as forest fragment edges). In Bahia, the species preferentially occur in ecotone areas of seasonal, caatinga, and cerrado forests. To other genera of Euphorbiaceae from Brazil such as Acalypha, Croton and Euphorbia, this occurrence for Atlantic forest also is predominant (Flora do Brasil 2020 , in construction).

Dalechampia L., Sp. Pl. 2: 1054. 1753.

Type: Dalechampia. scandens L. Species Plantarum: 105: 1753. Type: West Indies. Plantarum Americanarum fasciculus, 5: pl. 101 (original plate at P!, illustrated by Plumier).

Vine, liana or subshrub, monoecious; branches with tector trichomes, usually stinging. Leaves alternate, simple or compound, with petiolar stipules, and stipels at the base of leaf blade; lamina entire, 3-5-lobed or 3-5-foliolate, cordiform, linear, ovate, lanceolate; margins entire, slightly serrated, sinuate, serrulate or dentate, usually with glands, sometimes with stipitate glandular trichomes. Pseudanthium axillary, rarely terminal, bisexual, with 2 pairs of bracteal stipules, 2 involucral bracts; staminate pleiochasium and pistillate cymule centrally located; resiniferous glands formed by a set of bracteoles located next to the staminate pleiochasium. Involucral bracts entire to lobed, usually not unguiculate, magenta, yellowish, greenish or whitish. Staminate pleiochasium with $6-16$ flowers; $1-5$ bracteoles. Staminate flowers apetalous, pedicelate; sepals $4-6$, free, lanceolate; stamens 4-100, filaments united in a column, anthers showing longitudinal dehiscence. Pistillate cymule with 3 flowers; bracteoles 1-4. Pistillate flowers apetalous, pedicelate; sepals 6-12, free, lanceolate or ovate, entire, pinnatifid or laciniate; ovary globoid, 3-locular, 3-carpelar, 1 ovule per locule; stylar column cylindrical, stigma lobed, crateriform, clavate, discoid, cylindrical to peltate. Capsule with persistent stylar column, sepals, and involucral bracts. Seeds usually globoid, smooth or rugose, ecarunculate.

\section{Identification key to species of Dalechampia in northeastern Brazil}

1. Subshrub; staminate bracteoles and staminate sepals reddish

14. D. linearis

1. Liana or vine; staminate bracteoles greenish and staminate sepals pinkish or greenish ..... .2

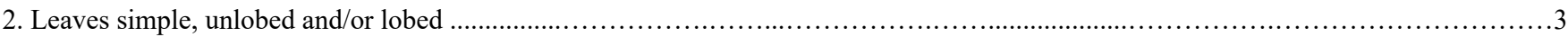

3. Leaves unlobed. 4. D. arciana

4. Leaves with margins sinuate, apex rounded, slightly apiculate; involucral bracts lanceolate ......................

4. Leaves with margins entire or dentate, apex acute, not apiculate; involucral bracts ovate to widely ovate 8. D. coriacea

5. Leaves coriaceous 1. D. affinis

5. Leaves membranaceous

6. Involucral bracts widely ovate, with 7 primary veins; ovary hispidous

6. Involucral bracts ovate, with 3-5 primary veins; ovary pubescent. . .7

7. Leaves cordiform; apex of the stylar column discoid. 7. D. convolvuloides

7. Leaves lanceolate to ovate; apex of stylar column discreetly crateriform to moderately lobed ....8

8. Branches and veins on the adaxial face of the leaves hirsute; involucral bracts $1.5-2 \mathrm{~cm}$ wide; pistillate sepals laciniate 13.D. leandri

8. Branches densely villous, and veins on the abaxial side of the leaves pubescent; involucral bracts $0.6-1 \mathrm{~cm}$ wide; pistillate sepals pinnatifid 22. D. schenckiana

3. Leaves lobed.. ....9

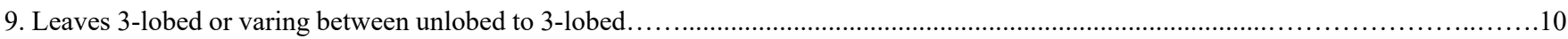

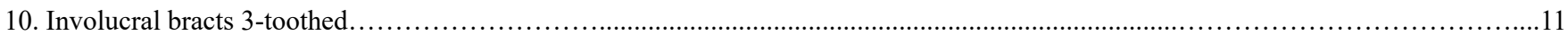

11. Leaves exclusively 3 -lobed...............................5. D. armbrusteri 11 . Leaves varying between unlobed to $3-$ lobed........12

12. Branches tomentose; apex of the stigma discoid to peltate; resiniferous gland fimbriate..... 26. D. tiliifolia

12. Branches pubescent; apex of the stigma crateriform, resiniferous gland lacerate 12. D. ilheotica 
10. Involucral bracts 3-lobed.

13. Pistillate sepals $8-12$, copiously glandular at tip.

14. Margins of leaves with papiliform glands; parastipule absent on the petiolar stipule

15. Liana; petiolar stipule ferruginous; bracteal stipule oblong.

11.D. ficifolia

15. Vine; petiolar stipule greenish; bracteal stipule linear, lanceolate or deltoid.

16. Involucral bracts chartaceous; stigma peltate to discoid.

17. Margins of involucral bracts ciliate; involucral bracts white at anthesis; bracteal stipule deltoid.

19. D. pernambucensis

17. Margins of involucral bracts not ciliate; involucral bracts yellowish at anthesis; bracteal stipule linear 10. D. fernandesii

16. Involucral bracts membranaceous; stigma crateriform to lobed...

22. D. scandens

18. Involucral bract greenish; bracteal stipule lanceolate; stigma slightly crateriform; resin of gland yellowish

6. D. brasiliensis

18. Involucral bract pale green; bracteal stipule linear; stigma slightly lobed, resin of gland white

...20

9. Leaves 5-lobed

2.D. alata

19. Branches greenish; pistillate sepals laciniate; upper half of the stylar column greenish after pollination; stigma clavate

9. D. erythrostyla

19. Branches vinaceous; pistillate sepals pinnatifid; upper half of the stylar column reddish after pollination, stigma lobate

2. Leaves compound

20. Staminate bracteole free; resin gland fimbriate.

21. Leaf 5-foliolate; involucral bracts deeply 3-5-lobed; pistillate sepals 6 entire.

18. D. pentaphylla

21. Leaf 3-foliolate, involucral bracts exclusively 3-lobed; pistillate sepals 6-12 pinnatifid ...

20. D. purpurata

22. Involucral bracts vinaceous; petiolar stipule and staminate bracteole vinaceous; pistillate sepals pink

22. Involucral bracts greenish, whitish or yellowish; petiolar stipule and staminate bracteole greenish; pistillate sepals greenish

24. D. subintegra

23. Stigma slender.

..........................24

23. Stigma cylindrical or moderately lobed

26. D. sylvestris

24. Pseudanthium 7-9 cm long; involucral bracts greenish to yellowish, stigma moderately lobed

...25

24. Pseudanthium 5-7 cm long; involucral bracts albido-virides or whitish, stigma cylindrical

25. Bracteal stipule 1-1.3 cm; ovary pubescent; stylar column glabrescent, 1.4-1.5 cm long; pistillate bracteole glabrous, ciliat

18. D. peckoltiana

25. Bracteal stipule ca. $8 \mathrm{~mm}$ long; ovary vellutinuos; stylar column pubescent, $1.2-1.3 \mathrm{~cm}$ long; pistillate bracteole pubescent, no ciliate ......

15. D. luetzelburgii

20. Staminate bracteole connate at the base, resin gland laminar

3. D. allemii

27. Involucral bract unguiculate, $0.7-1 \mathrm{~cm}$ wide; pistillate sepals 3 -fid

27. Involucral bract not unguiculate, $1.3-1.9 \mathrm{~cm}$ wide; pistillate sepals laciniate or pinnatifid .28

28. Adaxial leaf face glabrous; apex of stigma slender to moderately lobed; sepals on fruit 3-4 mm wide.

28. Adaxial leaf face sparsely hispidous; apex of stigma discoid; sepals on fruit 1-2 mm wide

16. D. olfersiana

1. Dalechampia affinis Müll. Arg. Linnaea 34: 223. 1865. Lectotype (designated by Webster \& Armbruster 1991): French Guyana, La Mana, 1856, P.A. Sagot s.n. (G!, isolectotype P! 2 sheets) Figure 2a \& 8a.

Dalechampia affinis is distinguished by having pistillate cymule sessile, pistillate bracteole widely ovate, pistillate sepals, ovary hispidous, stigma peltate, and a discoid stylar column. It can be confused with $D$. convolvuloides, as they share cordate leaves and pinnatifid sepals. They can be differentiated, however, by the numbers of veins (seven in D. affinis vs. three to five in D. convolvuloides), ovary hispid (vs. pubescent)

Distribution, ecology, and conservation: Dalechampia affinis occurs in South America from Venezuela to Brazil in rainforest environments (Webster \& Armbruster 1991). In Brazil, it is found in the northern (Amazonas, Amapá, Pará, Rondônia states), southeastern (Minas Gerais), and northeastern regions (Flora do Brasil, under construction 2020). In the northeast, it has been recorded in the states of
Maranhão and Piauí in gallery forests. A new occurrence is recorded here for Bahia in an Atlantic Forest environment. The species is designated, using IUCN (2001) criteria, as of least concern (LC) due to its EOO of ca. $5,947,112.590 \mathrm{~km}^{2}$, and as endangered (EN) due to its AOO of $272.000 \mathrm{~km}^{2}$.

Material examined: BRAZIL, BAHIA: Salvador, 1258'S, 38³0’W, 18.VII.1951, fl., O. Travassos 206 (RB). PIAUÍ: Piripiri, Estrada para pedro II, $4^{\circ} 20^{\prime} \mathrm{S}, 4^{\circ} 46^{\prime} \mathrm{W}, 05 . \mathrm{IV} .2002$, R.S. Rodrigues 1488 (TEPB). MARANHÃO: Viana, $03^{\circ} 13^{\prime}$ 'S, $45^{\circ} 00^{\prime} \mathrm{W}$, I.1960, fl., fr., O. Carvalho s.n. (RB 105148).

Additional material examined: BRAZIL, PARÁ: Jacundá, Rio Tocantins, 4²6'S, 496'W, 16.V.1978, fl., M.G. Silva \& R. Bahia 3591 (UB); Oriximiná, Cachoeira Porteira, 1²45'S, 5551'W, V.1981, fl., fr., C. Davidson s.n. (UB 117738). AMAPÁ: Macapá, Rodovia JK $2 \mathrm{~km}$, Cerrado do campus Marco Zero da UNIFAP, $0^{\circ} 2^{\prime} \mathrm{N}, 51^{\circ} 4^{\prime} \mathrm{W}$, 19.VI.2015, fl., R.S.F.R. Sarquis 274 (IAN). 
2. Dalechampia alata Müll.Arg. Linnaea 34: 220. 1865. Lectotype (designated by Webster \& Armbruster 1991): Brazil, Rio de Janeiro, Tocaia, Schott 4198 (W!). Figure 2b \& 8b.

Dalechampia alata was distinguished from other congeners by having a cuneate foliole base, laciniate pistillate sepals, and stigma clavate. It resembles $D$. erythrostyla, as both have parted leaves, 5-lobed, but are differentiated by the shape of the pistillate sepals (laciniate or slightly lobed in D. alata vs. pinnatifid in D. erythrostyla) and by the shape of the stigma (clavate in D. alata vs. slightly lobed in D. erythrostyla).

Distribution, ecology, and conservation: Dalechampia alata is endemic to Brazil, having been recorded in the southeastern (Espírito Santo, Rio de Janeiro and São Paulo) and northeastern regions of that country (Flora do Brasil 2020, under construction). In the study area, it is recorded for Bahia and Pernambuco, occurring in the caatinga and Atlantic Forests. Dalechampia alata is designated as of least concern (LC) considering it's EOO of ca. 1,389,947.159 km², and as endangered (EN) due to its AOO of $40.000 \mathrm{~km}^{2}$ (IUCN 2001).

Material examined: BRAZIL, PERNAMBUCO: São Lourenço da Mata, Tapera, $8^{\circ} 0^{\prime}$ S, 35' 'W, 06.III.1925, fl., D.B. Pickel 886 (IPA). BAHIA: Maracás, $13^{\circ} 26^{\prime}$ S, $40^{\circ} 25^{\prime}$ W, 05.V.1979, fr., S.A. Mori \& T.S. Santos s.n. (CEPEC 16131). ESPÍRITO SANTO: Santa Teresa, Estrada do 25 de Julho, 06.IV.1999, fr., L. Kollmann et al. 2376 (MBML); Santa Teresa, São João de Petrópolis, fl., fr., (fragmented), A. P. Fontana et al.21 (MBML).

3. Dalechampia allemii Webster, Ann. Missouri Bot. Gard. 78: 255257. 1991. Holotype: Brazil, Bahia, Andaraí, 50 km NW of Andaraí, A.C. Allem, G.L. Webster \& W.L. Werneck 2980 (CEN, isotype DAV!). Figure 2c \& 8c

Dalechampia allemii is easily differentiated from other congeners by having 3-foliolate leaves, unguiculate involucral bracts, and 3-fid pistillate sepals.

Distribution, ecology, and conservation: $D$. allemii is endemic to Brazil, and currently considered exclusive to Bahia (northeastern region), where it is found growing in Caatinga vegetation (Webster \& Armbruster 1991). We have expanded the amplitude of its distribution, however, with a new record here for Minas Gerais State (southeast) in a semideciduous montane forest. According IUCN criteria (2001), the species is designated as least concern (LC) by having an EOO of ca. $225,678.370 \mathrm{~km}^{2}$, and as endangered (EN) due to its AOO of 24.000 $\mathrm{km}^{2}$ (IUCN 2001). Part of the area in which the species occurs is located within the Morro do Chapéu State Park.

Material examined: BRAZIL, BAHIA: Wagner, 12¹6'S, 4110'W, 15.XI.1984, fl., A.C. Allem et al. 2980 (CEN).

Additional material examined: BRAZIL, MINAS GERAIS: Jequeri, área de inundação da usina de providência, $20^{\circ} 27^{\prime} \mathrm{S}, 42^{\circ} 39^{\prime} \mathrm{W}$, 19.XI.1997, fl., A. Salino 3752 (BHCB).

4. Dalechampia arciana Baill. Adansonia 5: 314. 1865. Lectotype: Brazil, Bahia, Jacobina, Pouço d'Areia, J.S. Blanchet 3884 (P!, isolectotypes BM!, G! 3 sheets, G-DC!, UC!). Figure 2d \& 8d.

Dalechampia arciana can be distinguished from other species in the group by having leaves chartaceous, ovate, with base subcordate to rounded, apex rounded, an involucral bract, and pistillate sepals entire.
Distribution, ecology, and conservation: The species is endemic to Brazil and can be found in the southeastern (Rio de Janeiro) and northeastern regions of that country (Flora do Brasil 2020, under construction). In the northeast, it is found only in Bahia State in caatinga environments. The species is designated, according IUCN (2001) criteria, as of least concern (LC) due to its EOO of ca. 858,606.243 $\mathrm{km}^{2}$, and as endangered (EN) due to its AOO of $36.000 \mathrm{~km}^{2}$. The area of occurrence of Dalechampia arciana includes three protected areas in southern Bahia: the Descobrimento National Park, Pau Brasil National Park, and the Una Wildlife Refuge.

Material examined: BRAZIL, BAHIA: Prado, Fazenda Riacho das Ostras, $17^{\circ} 19^{\prime}$ S, 39¹3W, 28.XI.2006, fl., S.G. Resende \& E.G. Resende 1699 (BHCB).

5. Dalechampia armbrusteri Webster, Brittonia 41:3. 1989. Holotype: Brazil, Bahia, grounds of CEPLAC, G.L. Webster \& S. Armbruster 25000 (CEPEC!, isotype DAV!). Figure 2e \& 8e.

Dalechampia armbrusteri can be recognized by its 3-lobed, chartaceous leaves and obtuse to rounded base of involucral bracts. It can be confused, with $D$. ilheotica for sharing 3-cuspidate involucral bracts, velutinous, and 7-9 primary veins. Additionally, both were described from the same locality (Ilhéus, in Bahia State). D. armbrusteri, however, as leaves exclusively 3-lobed (vs. varying between entire and 3-lobed in D. ilheotica) and a 3-lobed stigma (vs. crateriform).

Distribution, ecology, and conservation: Dalechampia armbrusteri is endemic to Brazil, with records for the southeastern (Espírito Santo State) (Flora do Brasil 2020, under construction) and northeastern (Bahia) regions of that country, growing in ombrophilous forest environments.

Material examined: BRAZIL. BAHIA: Una, Serra Boa, 15²17'S, 394'W, 28.IX.1979, fl., J.L. Hage \& L.A.M. Silva 317 (CEPEC).

6. Dalechampia brasiliensis Lam., Encycl. 2: 258. 1786. Lectotype (designated by Webster \& Armbruster 1991): Brazil, Rio de Janeiro, $J$. Dombey s.n. (P!, isotype NY!). Figure 3a \& 8f.

Dalechampia brasiliensis can be easily recognized by its linear bracteal stipules and pale green involucral bracts. The species has morphological affinities with both $D$. scandens and D. pernambucensis as they share 3-lobed leaves and pinnatifid pistillate sepals. They can be easily differentiated, however, by the shapes of their bracteal stipules, being linear in D. brasiliensis (vs. lanceolate in $D$. scandens, and deltoid in D. pernambucensis) and by the slightly lobed stigma in D. brasiliensis (vs. slightly crateriform in D. scandens, and peltate to discoid in D. pernambucensis).

Distribution, ecology, and conservation: Dalechampia brasiliensis is endemic to Brazil, growing in evergreen and seasonal forests (Webster \& Armbruster 1991). According to Flora do Brasil (2020, under construction), the species is widely disseminated in the central-western (Mato Grosso do Sul and Mato Grosso states), southeastern (Espírito Santo, Minas Gerais, Rio de Janeiro and São Paulo), and northeastern regions of the country. D. brasiliensis is found in the states of Alagoas, Bahia, Ceará, Paraíba, Pernambuco, and Sergipe, growing in Caatinga and Atlantic Forest environments. The species is designated, according to IUCN (2001) criteria, as of least concern (LC) due to its EOO of ca. 7, 836, 865. $094 \mathrm{~km}^{2}$, and vunerable (VU) due to its $\mathrm{AOO}$ of $536.000 \mathrm{~km}^{2}$. D. brasiliensis occurs in protected areas in northeastern Brazil, such as: the Chapada 
Diamantina National Park, Morro do Chapéu State Park, and the Raso da Catarina Ecological Station (all in Bahia), and in part of the Serra da Capivara National Park (Piauí State).

Material examined: BRAZIL, ALAGOAS: Matriz de Camaragibe, Santuário ecológico da Serra d'água, 95'S, 35³4'W, 26.VII.2003, fl., fr., R.P. Lyra-Lemos et al. 7805 (MAC). BAHIA: Senhor do Bonfim, Serra da Jacobina, $10^{\circ} 27^{\prime}$ S, $40^{\circ} 11^{\prime} \mathrm{W}, 29$.VII.2005, fl., V.J. Santos et al. 448 (HUEFS); Iaçu, 12²3'S, 3952'W, 12.III.1985, fl., fr., L.R. Noblick 3565 (HUEFS). CEARÁ: Crato, Lameiro, $7^{\circ} 24^{\prime} \mathrm{S}, 39^{\circ} 41^{\prime} \mathrm{W}$, 10.I.1982, fl., fr., A.L. Peixoto \& O.L. Peixoto 1657 (UEC). PARAÍBA: Coremas, Área de tensão ecológica, próximo a Serra, $07^{\circ} 00^{\prime} \mathrm{S}, 37^{\circ} 56^{\prime} \mathrm{W}$, 20.I.2010, fl., J.R. Andrade et al. 240 (PEUFR). PERNAMBUCO: Quipapá, Mata da Usina Água Branca, $8^{\circ} 49^{\prime}$ S, $36^{\circ} 0^{\prime} \mathrm{W}$, 10.I.1994, fl., A.M. Miranda 1170 (PEUFR). SERGIPE: Capela, RVS Mata do Junco, $10^{\circ} 32^{\prime}$ S, 3703'W, 30.IV.2013, fl, fr., L.A. Gomes et al. 1039 (ASE).

Additional material examined: BRAZIL, MINAS GERAIS: Itacarambi, $15^{\circ} 3^{\prime}$ S, $44^{\circ} 8^{\prime}$ W, 30.I.2010, fl., fr., E. Tameirão Neto \& C. Vidal 4756 (BHCB).

7. Dalechampia convolvuloides Lam., Encycl. 2: 256.1786. Holotype: Brazil, J. Dombey s.n. (P!). Figure $3 \mathrm{~b} \& 8 \mathrm{~g}$.

Dalechampia convolvuloides can be recognized by having petiolar stipules sparsely hispid, involucral bracts entire, ciliated, with cordate bases, bracteal stipules ovate with obtuse bases, and ovary pubescent. It resembles $D$. affinis, but can be distinguished from it by characters discussed above in the comments concerning that species.

Distribution, ecology, and conservation: Dalechampia convolvuloides is restricted to Brazil where it can be found in northern (Acre, Rondônia), southeastern (Minas Gerais, Rio de Janeiro and São Paulo), and northeastern regions of that country (Flora do Brasil 2020, under construction). In the study area, the states of Bahia, Pernambuco, Sergipe, and Piauí are largely covered by Caatinga and Atlantic Forest vegetations. The species is designated, according IUCN (2001) criteria, as of least concern (LC) due to its EOO of ca. 3,348,540.451 km², and as endangered (EN) due to its AOO of $96.000 \mathrm{~km}^{2}$. D. convolvuloides occurs in the Raso do Catarina Ecological Station (Bahia), Catimbau National Park (Pernambuco), Serra da Capivara National Park (Piauí), and the Araripe-Apodi National Forest (Ceará).

Material examined: BRAZIL, BAHIA: Salvador, Dunas de Itapuã, $12^{\circ} 56^{\prime}$ 'S, 38²1'W, 12.XII.1985, fl., L.R. Noblick \& I.C. Britto 4484 (HUEFS). PERNAMBUCO: Buíque, PARNA Catimbáu, 8³4'S, 37²15'W, 25.XI.2007, fl., B.S. Amorim \& A. Melo 2373 (NY). PIAUÍ: Teresina, Pq. Zoobotânico, 55'S, 4248'W, 03.02.1999, fl., F.S. Santos Filho 10 (PEUFR). SERGIPE: Mata do Crasto, Santa Luzia do Itanhy, $11^{\circ} 22^{\prime}$ S, 37²5'W, 15.IX.1995, M.F. Landim 659 (HUEFS).

Additional material examined: BRAZIL, ESPÍRITO SANTO: Santa Teresa, Estrada para o Cruzeiro, $1^{\circ} 56^{\prime}$ 'S, $40^{\circ} 35^{\prime}$ W, 8.V.1984, fl., fr., R.M. Piziolo 52 (MBML); Santa Teresa, Estrada para o Canaã, 1955'S, 40³7’W, 04.XII.1985, fl., J.M. Vimercat 322 (MBML). MINAS GERAIS: Santo Hipólito, 18¹7'S, 44¹1'W, 24.III.1997, fl., R.M. Silva et al. 1300 (BHCB).

8. Dalechampia coriacea Klotzsch ex Müll. Arg., Linnaea, 35: 223. 1865. Lectotype (designated by Webster \& Armbruster 1991): Brazil, without locality, F. Sellow s.n. (G!, isolectotype P!, W!) Figure 3c \& 8h.
Dalechampia coriacea can be recognized by having coriaceous leaves with dentate or entire margins, entire or 3-toothed involucral bracts, and pistillate sepals glabrous. It is morphologically similar to $D$. ilheotica in terms of the coriaceous consistency of their leaves, and $D$. coriacea can sometimes have entire leaves (similar to those of $D$. ilheotica). They can be differentiated, however, by having pubescent branches (vs. sparsely villous in $D$. ilheotica), lanceolate bracteal stipules (vs. linear), and a discoid stigma (vs. crateriform).

Distribution, ecology, and conservation: $D$. coriacea is endemic to Brazil (Webster \& Armbruster 1991), with records only for the northeastern region (Bahia and Pernambuco), being found in Caatinga and Ombrophilous Forest environments. According to IUCN (2001) criteria, the species is classified as of least concern (LC) due to its EOO of ca. 1,700, 173. $391 \mathrm{~km}^{2}$, and as endangered (EN) due to its AOO of $200.000 \mathrm{~km}^{2}$. Populations of this species can be found within the Serra das Confusões and Serra da Capivara National Parks (Piauí), the Araripe-Apodi National Forest (Ceará), the Catimbau National Park (Pernambuco), the Murici Ecological Station (Alagoas), the Raso do Catarina Ecological Station, Sete Passagens State Park, Morro do Chapéu State Park, and the Chapada Diamantina National Park (Bahia).

Material examined: BRAZIL, BAHIA: Itiruçu, $13^{\circ} 31^{\prime} \mathrm{S}, 40^{\circ} 9^{\prime} \mathrm{W}$, 12.XI.1984, fl., A.C. Allem \& W.L. Werneck 2949 (CEN); Santa Terezinha, Serra da Jibóia, 1246’S, 39³1'W, 08.VII.1999, F. França et al. 3201 (CEN). PERNAMBUCO: Igarassu, Usina São José, $7^{\circ} 46^{\prime}$ 'S, $35^{\circ} 00^{\prime}$ W, 1.XII.2011, fl., fr., B.S. Amorim et al. 1309 (NY).

9. Dalechampia erythrostyla R. A. Pereira-Silva \& A. L. Melo, Syst. Bot. 41: 989-995. 2016. Holotype: Brazil, Pernambuco, Tracunhaém, engenho Trapuá, 27 May 2014, R. Pereira-Silva \& A. Laurênio 16(IPA!, isotypes K!, NY!, P!, PEUFR!, RB!, SP!). Figure 3d \& 9a.

Dalechampia erythrostyla can be recognized by having branches vinaceous, pistillate pinnatifid sepals, involucral bracts cuneate, resiniferous glands fimbriate, a reddish coloration on the upper half of the stigma following pollination, and cylindrical stigma. The taxon is often confused with $D$. alata, but can be differentiated by aspects discussed above in the comments on that species.

Distribution, ecology, and conservation: D. erythrostyla is currently known only to Brazil, in the states of Bahia, Pernambuco, and Sergipe in the northeast region of that country (Pereira-Silva et al. 2016). The record for Sergipe is presented here for the first time. $D$. erythrostyla was found in those areas in the Atlantic Forest and at the edges of sub-deciduous forests. The species was considered as least concern (LC) due to its EOO of ca. $51,333.737 \mathrm{~km}^{2}$, and as endangered (EN) due to its $\mathrm{AOO}$ of $12.000 \mathrm{~km}^{2}$.

Material examined: BRAZIL, PERNAMBUCO: Tracunhaém, Engenho Trapuá, $7^{\circ} 48^{\prime}$ 'S, $35^{\circ} 14^{\prime}$ W, 1.II.2014, fl., R.A. Pereira-Silva \& A. Laurênio 12 (PEUFR); idem, 13.II.2014, fl., R. A.Pereira-Silva 14 (PEUFR); idem, 27.V.2014, fr., R. A.Pereira-Silva \& L. Lima-Santos 16 (PEUFR); idem, 27.VI.2014, fl., fr., R.A. Pereira-Silva 18 (PEUFR). BAHIA: Jacobina, $11^{\circ} 10^{\prime} \mathrm{S}, 40^{\circ} 30^{\prime} \mathrm{W}, 25 . \mathrm{VIII} .1980$, fl., Orlandi, R. 219 (HBR). SERGIPE: Divina Pastora, Fazenda Vassouras, $10^{\circ} 40^{\prime} \mathrm{S}$, 379'W, 18.XI.2014, fl., J.A. Santana Júnior, et al. 41 (ESA).

10. Dalechampia fernandesii Webster, Brittonia 41:1. 1989. Holotype: Brazil, Ceará, Chapada da Ibiapaba, G.L. Webster, Fernandes \& Matos 25598 (EAC!, isotypes DAV!, NY, R, UCR!). Figure 3e \& 9 b. 
Dalechampia fernandesii can be distinguished from other congeners by havingbracteal stipules linear involucral bracts 3-lobed, yellowish, vellutinous with proeminent veins, pistillate bracteole widely ovate and stigma peltate to discoid Dalechampia brasiliensis share the shape of bracteal stipules, but they differ in multiple aspects such as texture, color and primary veins of involucral bracts, beyond the shape of stigma.

Distribution, ecology, and conservation: $D$. fernandesii is endemic to Brazil, being encountered only in the northeastern region of that country (the states of Ceará, Maranhão, and Piauí) in Caatinga vegetation. The species is categorized, according to IUCN (2001) criteria, as vulnerable (VU) due to its EOO of ca. 9, 462. $023 \mathrm{~km}^{2}$, and as endangered (EN) due to its AOO of $12,000 \mathrm{~km}^{2}$. One of its known populations occurs in the vicinity of the Aiuaba Ecological Station in Ceará state.

Material examined: BRAZIL, CEARÁ: Aracati, 433' $\mathrm{S}, 3^{\circ} 46^{\prime} \mathrm{W}$, 30.V.1987, A. Fernandes \& A. Nunes s.n. (EAC 15262); JaburunaSul, Planalto do Iapaba-Ubajara, 353'S, 4058'W, 06.VI.1994, F.S. Araújo 807 (EAC); Tianguá, Chapada da Ibiapara, 034' S, 4059' W 01.XI.1986, fl., G.L. Webster et al. s.n. (EAC 14892). MARANHÃO: Timon, 0505'S, 4250'W, 29.IV.1978, fl., A. M. Fernandes \& E. Matos s.n. (EAC 3832). PIAUÍ: Between Parnaíba and Piracuruca, $2^{\circ} 54$ 'S, 41ํㄴ' 'W, 28.VI.1984, A. M. Fernandes \& E. Matos s.n. (EAC 12725).

11. Dalechampia ficifolia Lam., Encycl. 2: 258.1786. Holotype: Brazil, without locality, J. Dombey s.n. (P!). Figure 4a \& 9c.

Dalechampia ficifolia is characterized by having oblong bracteal stipules, ferruginous, velutinous, and a 3-lobed to clavate stylar column. The species is similar to $D$. stipulacea, but can be differentiated by the length of the bracteal stipules in D. ficifolia $(0.4-0.2 \mathrm{~cm}$ vs. $1.3-1.5 \mathrm{~cm}$ in D. stipulacea) and by the shape of the stigma shape in D. ficifolia (discoid to crateriform vs. lobed in D. stipulacea).

Distribution, ecology, and conservation: $D$. ficifolia is considered endemic to Brazil, although widely disseminated in all of its regions, growing predominantly in rainforest areas (Webster \& Armbruster 1991). It is encountered in the central-western (Distrito Federal, Goiás), southeastern (Espírito Santo, Minas Gerais, Rio de Janeiro, and São Paulo), and southern (Paraná and Santa Catarina) regions of the country (Flora do Brasil 2020, under construction). It is found in Bahia, Pernambuco, and Sergipe in ecotone areas between forest and Caatinga zones. The species is designated, according IUCN (2001) criteria, as of least concern (LC) due to its EOO of ca. 10, 552, 361.913 $\mathrm{km}^{2}$, and as vulnerable (VU) due to its AOO of $748.000 \mathrm{~km}^{2}$. One of its populations has been recorded in the Chapada Diamantina National Park (Bahia); the extent of occurrence of the species includes several protected areas, such as: the Araripe-Apodi National Forest (Ceará), Catimbau National Park (Pernambuco), Raso do Catarina Ecological Station, Morro do Chapéu State Park, the Brejo Grande Ecological Reserve (Bahia), Serra das Confusões National Park, and the Serra da Capivara National Park (Piauí).

Material examined: BRAZIL, BAHIA: Santa Tereza, Serra da Jibóia, 1251'S, 39²8'W, 01.XI.1992, L.P. Queiroz et al. 20891 (BHCB). PERNAMBUCO: São Vicente Férrer, Mata do Estado, $7^{\circ} 35^{\prime}$ S, 35³0’W, 29.X.1984, E.M.N. Ferraz et al. 602 (PEUFR). SERGIPE: Mata do Crasto, Santa Luzia do Itanhy, $11^{\circ} 22^{\prime}$ S, 37²5'W, 30.X.1995, fl., fr., M.F. Landim 750 (ASE).
Additional examined material: BRAZIL, SANTA CATARINA: Blumenau, 265'ㅇ, 494'W, 05.XII.2012, fl., L.A. Funez 1299 (FURB); Bairro Ristow, 21.X.2009, fl., A. Korte 669 (FURB). SÃO PAULO: Ubatuba, Acesso ao Condomínio Laranjeiras, $23^{\circ} 25^{\prime} \mathrm{S}$, 455'W, 31.I.1996. fl., H.F. Leitão Filho et al. 34413 (UEC). MINAS GERAIS: Descoberto, reserva Biológica da Represa do Grama, 2127'S, $42^{\circ} 58^{\prime}$ W, 10.XI.2001, fl., J.O. Augustin et al. s.n. (CESJ 35081).

12. Dalechampia ilheotica Wawra, Oesterr. Bot. Z. 13: 222. 1863. Holotype: Brazil, Bahia, Ilhéus, Wawvra \& Maly 365 (W!, isotype W!). Figure $4 b$ \& $9 d$

Dalechampia ilheotica resembles $D$. coriacea and $D$. armbrusteri by aspects already presented for those species. D. ilheotica is characterized by having simple leaves, coriaceous or membranous, it is possible find individuals with unlobed leaves or 3-lobed, or yet ranging from unlobed to 3-lobed even on the same individual, as well as the involucral bracts can be unlobed or 3-toothed and apex of stigma crateriform.

Distribution, ecology, and conservation: D. ilheotica has been recorded for Colombia and Brazil. In Brazil, it has been collected in the southeastern (Espírito Santo) and northeastern (Bahia and Pernambuco) regions, growing in Atlantic Forest environments such as restinga (Webster \& Armbruster 1991, Flora do Brasil 2020, under construction). It is found in ombrophilous forest and restinga environments in the states of Bahia and Pernambuco, and is designated, according IUCN (2001) criteria, as of least concern (LC) due to its EOO of ca. 4, 509, 418. $463 \mathrm{~km}^{2}$, and as endangered (EN) due to its AOO of 268,000 $\mathrm{km}^{2}$. The largest number of populations is found in Bahia, where the species is disseminated throughout the state, growing in the Cassurubá Extractive Reserve, the Una Wildlife Refuge, and Serra das Lontras National Park. Considering its extent of occurrence, however, it is probable that populations of $D$. ilheotica occur in other protected areas in Bahia, such as: the Pau Brasil National Park, Descobrimento National Park, Canavieiras Extractivist Reserve, Boa Nova National Park, Morro do Chapéu Park State, Raso do Catarina Ecological Station, and the Chapada Diamantina National Park.

Material examined: BRAZIL, PERNAMBUCO: Maraial, $8^{\circ} 48^{\prime} \mathrm{S}$, 3545’W, 10.II.1994, fr., A.M. Lourenço 1317 (PEUFR); São Vicente Ferrer, $7^{\circ} 35^{\prime}$ S, 35²9'W, 20.I.1999, fl. E. M. N. Ferraz et al. 602 (PEUFR). BAHIA: Uruçuca, Distrito de Serra Grande, $14^{\circ}$ 35' S, $39^{\circ}$ 17’W, 07.IX.1991, A.M. Carvalho et al. 3646 (SP).

13. Dalechampia leandri Baill. Adansonia 5:315. 1865. Lectotype (designated by Webster \& Armbruster 1991): Brazil, Rio de Janeiro, Leandro di Sacramento 110 (P!). Figure 4c \& 9e.

Dalechampia leandri can be recognized by having hirsute trichomes on its branches, the veins of the abaxial surface of leaves, and on the pistillate laciniate sepals; leaf margins undulate, and laminar resiniferous glands. It resembles $D$. schenckiana as they share lanceolate leaves; they can be differentiated, however, by the hirsute branches of $D$. leandri (vs. densely villous in D. schenckiana), involucral bracts ranging between unlobed to 3-toothed (vs. always unlobed), laciniate sepals (vs. pinnatifid), and hirsute trichomes on the leaf veins (vs. pubescent).

Distribution, ecology, and conservation: $D$. leandri is endemic to Brazil, being known from the southern (Paraná) and southeastern (Rio de Janeiro and São Paulo) regions of the country (Flora do Brasil 2020, under construction). It is cited here for the first time in the study 
area, occurring in Paraiba state. The species is designated, according IUCN (2001) criteria, as least concern (LC) due to its EOO of 344, $331.752 \mathrm{~km}^{2}$ and as endangered (EN) due its AOO of $28.000 \mathrm{~km}^{2}$. A population of that species has been recorded in the Guaribas Biological Reserve (Paraíba State).

Material examined: BRAZIL, PARAÍBA: Mamanguape, Reserva ecológica Guaribas, 6 $6^{\circ} 43$ 'S, 358'W, 07.VII.2015, fl., R.A. PereiraSilva, 32 (PEUFR).

Additional examined material: BRAZIL, SÃO PAULO: Pariquera-Açú, 2442’'S, 4752'W, 16.II.1995, fl., H. F. Leitão Filho et al. 33192 (UEC); Estrada Pariquera-Açú para Cananéia, 2442'S, 4752’W, 07.II.1995, fl., H.F. Leitão Filho et al. 32727 (UEC). PARANÁ: Paranaguá, Morro do Meio, 25³0'S, 48³1'W, 13.XII.1986, fl., R.M. Britez 1257 (UPCB). RIO DE JANEIRO: Parque Nacional da Tijuca, 22 $56^{\prime}$ 'S, 43ำ17'W, 27.X.1984. fl., G.L. Webster et al. 25429 (UEC).

14. Dalechampia linearis Baill. Adansonia 5: 316-317. 1865. Lectotype (designated by Webster \& Armbruster 1991): Brazil, Goiás, Rio Pilões, St. Hilaire $C^{l} 801$ (P!, isotype P!). Figure 4d \& 9f.

Dalechampia linearis can be distinguished from congeners by having a subshrub habit, simple and linear to lanceolate leaves, 3-lobed involucral bracts, lanceolate stipules, and a lobed stigma. This species can be confused with $D$. caperonioides, a species presently recorded for the central-western region of Brazil. D. linearis, however, has a 3-lobed, greenish to vinaceous bracteole (vs. entire, whitish, or pinkish in D. caperonioides), and 12 pistillate pinnatifid sepals (vs. 6 entire).

Distribution, ecology, and conservation: $D$. linearis has been recorded for Paraguay and Brazil. In Brazil, there are records for the northern (Pará and Tocantins), central-western (Distrito Federal, Goías, and Mato Grosso), and northeastern regions (Flora do Brasil 2020, under construction). In the latter region, the species is found in the states of Maranhão and Piauí. It is recorded here, for the first time, for Bahia, with occurrences in both caatinga and cerrado vegetation. The species is designated, according IUCN (2001) criteria, as of least concern (LC) due to its EOO of ca. 1,769, 053. $532 \mathrm{~km}^{2}$, and as endangered (EN) due to its AOO of $352.000 \mathrm{~km}^{2}$. None of the specimens analyzed came from protected areas in the two northeastern states. It is possible, however, that greater collection efforts will result in new findings in protected areas within the range of occurrence of the species, such as: the Parnaíba River National Park, the Uruçuí-Una Ecological Station, and the Serra das Confusões National Park (Piauí)

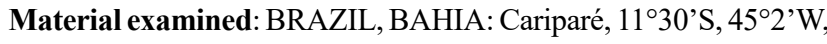
17.XII.1987, fl., T.S. Figueiras 1289 (CEN). MARANHÃO: Balsas, $7^{\circ} 31^{\prime}$ 'S, 46²'W, 18.XI.1997, fl., R.C. Oliveira \& G.P. da Silva 545 (CEN). PIAUÍ: Ribeiro Gonçalves, 7³2'S, 45¹4'W, 17.X.1980, fl., A. Fernandes \& A.J. Castro s.n. (EAC); Ribeiro Gonçalves, $7^{\circ} 32^{\prime} \mathrm{S}$, 45¹4'W, 10.XII.1980, fl., M.R. Del'Marco et al. s.n. (TEPB 1417).

Additional material examined: BRAZIL, GOIAS: Estrada em direção ao centro de Goias, $15^{\circ} 55^{\prime} \mathrm{S}, 50^{\circ} 07^{\prime} \mathrm{W}, 30 . \mathrm{XI} .2011$, fl., fr., R.F. Monteiro et al. 437 (CEN); Colinas do Sul, Niquelânia, 14¹6'S, 4809'W, 22.IV.2010, fl., J.E.Q. Faria et al. 835 (CEN). TOCANTINS: Almas, Estrada para Natividade, $11^{\circ} 37^{\prime}$ S, $47^{\circ} 23^{\prime} \mathrm{W}, 22$.VII.2000, V.C. Souza et al. 24514 (CEN); Itacajá, Reserva Indígena Krahó, Aldeia Pedra Branca, $08^{\circ} 18^{\prime}$ S, $47^{\circ} 38^{\prime}$ W, 06.V.2000, fl., A.A. Santos et al.
650 (CEN); Parana, $3^{\circ}$ parada após a ponte sobre o Rio São Domingos, $12^{\circ} 55^{\prime}$ 'S, $47^{\circ} 41^{\prime}$ W, 28.III.2004, fl., A.C. Sevilha et al. 3906 (CEN).

15. Dalechampia luetzelburgii Pax \& Hoffm., Pflanzenr. IV. 147. XVII (Heft 68): 188 1924. Lectotype (designated by Athiê-Souza et al. 2018). Brazil, Bahia, São Bento das Lages, 1913, von Lützelburg 132 (M! M0233664, isolectotype M! M0233665). Figure 5a \& 9g.

Historically the species with 3 -foliolate leaves form a complex of difficult identification as discussed by Allem and Waechter (1977) and commented by Armbruster \& Webster (1991). D.luetzelburgii, $D$. peckoltiana and $D$. sylvestris are very close morphologycally due this kind of leaves and the shape of involucral bracts, deeply 3-lobed. Comparing the size and color of involucral bracts these are 5-6 cm long, whitish in D. luetzelburgii (vs. 5-6 cm long, albido viridis and $7-9 \mathrm{~cm}$ long, pale green in D. peckoltiana and D. sylvestris, respectively). The stylar column is $1.2-1.3 \mathrm{~cm}$ long (vs. $1.4-1.5 \mathrm{~cm}$ long and $0.8-1 \mathrm{~cm}$ long). The number of pistillate sepals is the same for D. luetzelburgii and D. peckoltiana (6) (vs. ca. 9 in D. sylvestris). In addition, pseudanthium of Dalechampia luetzelburgii and D. peckoltiana also is similar to $D$. subintegra in the shape of involucral bracts and number of pistillate sepals (6). But, they differ by the bracteal stipules deltoid to lanceolate (vs. linear in D. subintegra) and stigma cylindrical (vs. slender).

These species need more investigation as phylogenetic analyzes or other tools that may help in identifying.

Distribution, ecology, and conservation: $D$. luetzelburgii has been recorded from the northern (Pará) and northeastern regions of Brazil (Flora do Brasil 2020, under construction); the species in the latter region (in the states of Bahia and Ceará) occur in Atlantic Forest environments. D. luetzelburgii is included in the category of least concern, as its EOO is ca. $1,125,778.391 \mathrm{~km}^{2}$, and as endangered (EN) due to its AOO of $88.000 \mathrm{~km}^{2}$. The species is found in protected conservation areas such as the Araripe National Forest (Ceará) and the Pau-Brasil Ecological Station (Bahia).

Material examined: BRAZIL. BAHIA: Santa Cruz Cabrália. Estação Ecológica do Pau-Brasil 7.V.1984, F.S. Santos 325 (CEPEC). CEARÁ. Crato, chapada do Araripe, $7^{\circ} 16^{\prime}$ S, 39³2W, 19.I.1983, fl., fr., T. Plowman 12736 (NY); Guaramiranga, Serra de Baturité, 09.VIII.1993. fl., M. R. L. Oliveira 59 (EAC). PARÁ. Rio Tocantins: nella foresta Capuera Roca presso Itacayuna 1.VII.1899. L. Buscalioni $3650(\mathrm{NY})$.

16. Dalechampia olfersiana Müll. Arg., Linnaea 34: 280. 1865. Lectotype (designated by Webster \& Armbruster 1991): Brazil, without locality, F. Sellow 636 ex p. (G!, isolectotype F!). Figure 5b \& 9h.

Dalechampia olfersiana is characterized by having compound leaves, 3-foliolate, pistillate sepals 7 to 8 , pinnatifid, involucral bracts $1.3-1.5 \times 1.3-1.8 \mathrm{~cm}, 3$-lobed, green, with papilliform glands and a discoid stigma.

Distribution, ecology, and conservation: D. olfersiana is endemic to the southeastern (Minas Gerais, Rio de Janeiro, and São Paulo) and northeastern regions of Brazil (Flora do Brasil 2020, under construction). It occurs in the northeast in the states of Bahia and Pernambuco in caatinga, ombrophilous forest, semideciduous seasonal forest, and gallery forest environments. The species is designated, 
according to IUCN (2001) criteria, as least concern (LC) due to its EOO of $1,316,190.235 \mathrm{~km}^{2}$, and as endangered (EN) due to its AOO 20. $000 \mathrm{~km}^{2}$ (IUCN 2001).

Material examined: BRAZIL, BAHIA: Maracás, $13^{\circ} 31^{\prime}$ 'S, 40³3'W, 22.IV.2002, fl., K.R.B Leiite et al 212 (HUEFS). PERNAMBUCO: Brejo da Madre de Deus, 88'S, 36²2'W, 04.II.1995, M.J.N. Rodal et al. 456 (PEUFR).

Additional material examined: BRAZIL, MINAS GERAIS: Serra do Cipó, Santana do Riacho, 19¹0’S, 4342’W, 27.IV.1993, fr., J.A. Lombardi \& F.R.N. Toledo 189 (BHCB).

17. Dalechampia peckoltiana Müll. Arg., in Martius, Fl. Bras. 11(2): 647. 1874. Holotype: Brazil, Rio de Janeiro, Canta Gallo, Peckolt 93 (M, isotypes BR!, G!). Figure 5c \& 9i.

Dalechampia peckoltiana is distinguished by its pseudanthium with deeply 3-lobed, whitish, involucral bracts and deltoid to lanceolate bracteal stipules.It demonstrates morphological similarities with $D$. subintegra and $D$. luetzelburgii by sharing shape of involucral bracts and leaves. They can be distinguished by the characteristics noted in the comments above concerning $D$. luetzelburgii.

Distribution, ecology, and conservation: D. peckoltiana is endemic to Brazil, having originally been considered to be restricted to Rio de Janeiro (southeast) (Webster \& Armbruster 1991). The species is currently known to the states of Espírito Santo and Minas Gerais (both in the southeastern region), and to the northeast (Flora do Brasil 2020, under construction). In the northeast, the species can be found in Alagoas, Bahia, Pernambuco, and Sergipe, in caatinga and ombrophilous forest environments. The species is designated, according to IUCN (2001) criteria, as of least concern (LC) due to its EOO of ca. $987,171.633 \mathrm{~km}^{2}$, and as endangered (EN) due to its AOO of 272.000 $\mathrm{km}^{2}$ (IUCN 2001). Some populations occur in and around the Chapada Diamantina National Park (Bahia), and several populations have been recorded from the vicinity of the Sete Passagens State Park (Bahia). According to the geographic extension of the species, it is expected that some populations will be found in other protected areas in Bahia State, such as: the Canavieiras Extractivist Reserve, the Serras das Lontras National Park, and the Una Wildlife Refuge.

Material examined: BRAZIL, ALAGOAS: Coruripe, Usina Coruripe, Mata do Riachão, $10^{\circ} 02$ 'S, $36^{\circ} 16^{\prime} \mathrm{W}, 04 . X I .2002$, fl., W.W. Thomas et al. s.n. (NY 13268). BAHIA: Jacobina, Itaitu, Cachoeira do Véu da Noiva, 11¹0' S, 40³1'W, 24.IV.1999, fl., R.C. Forzza, A.M. Amorim \& Sant'Ana 1337 (SP); Lençois, Pai Inácio, 12²8'S, 41²7’ W, 12.III.1997, P. Gasson \& L. Natalino 6210 (SP). PERNAMBUCO: Tapera, 9²5'S, 4045'W, 1936, fl., B. Pickel 4210 (IPA). SERGIPE: Nossa Senhora do Socorro, Floresta Nacional do Ibura, $10^{\circ} 83^{\prime} \mathrm{S}$, 37²13'W, 02.X.2014, J.P. Santana 347 (ASE).

18. Dalechampia pentaphylla Lam. Encycl. Botanique 2: 258. 1786. Holotype: Brazil, probably near Rio de Janeiro, 1790, Vandelli s.n. (P). Figure 6a \& 9j.

Dalechampia pentaphylla can be recognized by having compound leaves, 5-foliolate and deeply involucral bracts, 5-lobed, and six entire pistillate sepals. The species demonstrates morphological similarities with $D$. alata and $D$. erythrostyla. They can be easily differentiated, however, as D. pentaphylla has 5-foliolate compound leaves (vs. the pseudo-compound, deeply 5-lobed leaves of $D$. alata and D. erythrostyla), 5-lobed involucral bracts (vs. 3-lobed in $D$. alata and D. erythrostyla), and six entire pistillate sepals (vs. 12, laciniate or slightly lobed sepals in D. alata and 12 pinnatifid sepals in D. erythrostyla).

Distribution, ecology, and conservation: D. pentaphylla is not endemic to Brazil also occur in San Jose, Paraguay next to Mato Grosso do Sul. In Brazil, occurring in the central-western (Goiás and Mato Grosso do Sul), southeastern (Espírito Santo, Minas Gerais, Rio de Janeiro, and São Paulo), southern (Paraná), and northeastern regions of that country (Flora do Brasil 2020, under construction). In the northeastern region, it only occurs in Bahia State, where it was found in transitional areas between seasonal caatinga and cerrado forests. The species is designated, according to IUCN (2001) criteria, as of least concern (LC) due to its EOO of ca. 2,597, 337. $417 \mathrm{~km}^{2}$, and as endangered (EN) due to its AOO of $196.000 \mathrm{~km}^{2}$. Considering the geographic coverage of the species, individuals will probably be encountered in the Boa Nova National Park (Bahia).

Material examined: BRAZIL, BAHIA: Jaguaquara, Cascalheira, $13^{\circ} 31^{\prime}$ S, 3958'W, 13.X.2012, fl., W. Milliken et al. 5048 (HURB).

Additional examined material: BRAZIL, SÃO PAULO: São Pedro, Cachoeira da Peroba, 22 ${ }^{\circ} 33^{\prime}$ S, 47 $7^{\circ} 55^{\prime}$ W, 30.I.1992, fl., S. Gandolfi et al. s.n. (ESA 33223); Campinas, Santa Elisa, 2255'S, 470' 'W, 15.IV.1992, fl., fr., J.A. Lombardi 15 (BHCB). ESPÍRITO SANTO: Alegre, Parque Nacional do Caparaó, $20^{\circ} 23^{\prime}$ S, $41^{\circ} 44^{\prime}$ W, 22.II.2000, fl., V.C. Souza et al. 23673 (ESA). MINAS GERAIS: Carandaí, Pedra do Sino Hotel Fazenda, $20^{\circ} 52^{\prime}$ 'S, $43^{\circ} 48^{\prime}$ W, 29.XII.2005, N.F.O. Mota \& P.L. Viana 491 (ICB).

19. Dalechampia pernambucensis Baill., Adansonia 5: 311. 1865. Holotype: Brazil, Pernambuco, G. Gardner 1130 (G!, isotypes BM, K! 2 sheets, P!). Figure $5 \mathrm{~d} \& 10 \mathrm{a}$

Dalechampia pernambucensis is characterized by having deltoid bracteal stipules, involucral bracts that vary from whitish to greenish, with glandular trichomes on their margins, and the stylar column peltate to discoid. D. pernambucensis is commonly confused with D. brasiliensis and D. scandens, but can be differentiated by aspects already mentioned in the comments above concerning $D$. brasiliensis.

Distribution, ecology, and conservation: $D$. pernambucensis is endemic to Brazil, having been recorded in the northern (Amazonas, Pará, and Roraima) and northeastern regions of the country (Flora do Brasil 2020, under construction). In the northeastern region, D. pernambucensis can be found in Bahia, Ceará, Paraíba, and Pernambuco. In the study area, it has been identified in caatinga and Atlantic Forest vegetations. Dalechampia pernambucensis is considered of least concern (LC) due to its EOO of ca. 3, 051, $723.353 \mathrm{~km}^{2}$, and as endangered (EN) due to its $\mathrm{AOO}$ of $400.000 \mathrm{~km}^{2}$. Populations of this species are widely disseminated in the study region and have been recorded in the Araripe-Apodi National Forest and Aiuaba Ecological Station (Ceará). Taking into account the extent of expected occurrence of the species, populations may be encountered in other protected areas in the region (Catimbau National Park in Pernambuco, Raso do Catarina Ecological Station, Boa Nova National Park, Serras das Lontras National Park, and Una Wildlife Refuge in Bahia, and the Parnaíba River National Park on the borders of the states of Piauí, Maranhão, Bahia, and Tocantins). In the study area, it was found here for the first time in Piauí state. 
Material examined: BRAZIL, BAHIA: Caetité, $14^{\circ} 03^{\prime} \mathrm{S}, 42^{\circ} 28^{\prime} \mathrm{W}$, 19.II.1992, fl., A.M. Carvalho et al. 3771 (CEPEC). CEARÁ: Meruoca, Sítio Santo Antônio dos Fernandes, 3³2'S, 40²7’W, 26.V.1994, fl., fr., A.S. Fernandes s.n. (EAC 20877); Caridade, 45'S, 39³'W, 06.V.1990, fl., B. Freitas s.n. (EAC 16780); $11 \mathrm{~km}$ de Canindé pela BR 02, $4^{\circ} 21^{\prime}$ 'S, 39¹8’W, 27.I.1990, fl., I. Cordeiro \& J.R. Pirani 520 (SP). PARAÍBA: Remígio, 655'S 3553'W 17.III.1975, fl., V.P. Barbosa 231 (RB). PERNAMBUCO: Goiana, Itapirema, 07³3'S, 3500’W, 06.IV.1983, fl., fr., A. Chiappeta \& R. Barreto 497 (IPA). PIAUÍ: Cocal, Baixão, $3^{\circ} 28^{\prime}$ 'S, 41³0’W, 29.III.2003, E.M.F. Chaves \& E.M.S. Júnior s.n. (TEPB 19255).

20. Dalechampia purpurata Cordeiro, Kew Bulletin 53: 467. 1998. Holotype: Brazil, Bahia, Abaíra, Stannard, Ganev \& Queiroz H. 51654 (SPF!, isotypes K!, SP!). Figure 6b \& $10 \mathrm{~b}$.

Dalechampia purpurata differs from the other species of Dalechampia in the Northeast, because among the species with compound leaves, 3-foliolate, it is the unique with 3-lobed involucral bracts magenta and slightly lobed stigma.

Distribution, ecology, and conservation: $D$. purpurata is endemic to Brazil (Flora do Brasil 2020, in constr.), and restricted to Bahia State in caatinga environments. In terms of conservation status, Dalechampia purpurata is included in the category of vulnerable (VU) species because of its EOO of ca. 10, 659. $277 \mathrm{~km}^{2}$, and as endangered (EN) due to its AOO of $24,000 \mathrm{~km}^{2}$.

Material examined: BRAZIL, BAHIA: Abaíra, $13^{\circ} 16^{\prime} \mathrm{S}, 41^{\circ} 44^{\prime} \mathrm{W}$, 31.I.1992, fl., D.J.N. Hind et al. 51399 (K); Abaíra, 13²16'S, 41²4'W, 28.II.1992, fl., B. Stannard et al. 51654 (NY).

21. Dalechampia scandens L. Sp. P1. 2: 1054. 175. Holotype: West Indies, illustrated by Plumier, Plantarum Americanarum fascículos, 5: pl. 101 (original plate at P). Figure 6c \& 10c.

Dalechampia scandens can be distinguished from its congeners mainly by having lanceolate bracteal stipules and a slightly crateriform stigma. D. scandens can be confused with $D$. brasiliensis, but differs from it by characteristics already mentioned above for the latter species.

Distribution, ecology, and conservation: $D$. scandens is not endemic to Brazil, occurring in Central America, the Antilles, and South America (Webster \& Armbruster 1991). It is widely distributed in Brazil, occurring in the northern (Amazonas, Pará, Rondônia and Roraima), central-western (Mato Grosso do Sul and Mato Grosso), southeastern (Minas Gerais and São Paulo), and northeastern regions of the country (Flora do Brasil 2020, in constr.). In the study area, it has been recorded from Bahia, Ceará, Maranhão, Paraíba, and Pernambuco, growing in caatinga and Atlantic Forest vegetations. The species is herein designated as of least concern (LC), according to IUCN red list (IUCN 2001) criteria, because its populations are numerous and widespread throughout the study region.

Material examined: BRAZIL, BAHIA: Barra, Ibiraba, 104' $\mathrm{S}$, 4250'W, 22.II.1997, fl., L.P. Queiroz 4768 (TEPB). CEARÁ: Caridade, 041'ㅇ, 39¹1'W, 08.IV.2002, A. Fernandes s.n. (EAC 31381). PARAÍBA: São José dos Cordeiros, RPPN Fazendo Almas, 7²8'S, 36 53'W, 15.VIII.2010, fl., R.M.T. Costa \& M.F.M. Brito 151 (RB). PERNAMBUCO: Ouricuri, Tamboril, 0752'S, 4004'W, 10.III.1982, fl., V.C. Lima et al. 206 (IPA).
Additional material examined: BRAZIL, SÃO PAULO: Parque Estadual da Ilha Anchieta, $23^{\circ} 32^{\prime}$ S, 454'W, 08.IX.2008, fl., V.B. Zipparro 2504 (HRCB). MATO GROSSO: Poconé, Fazenda Corizal, $16^{\circ} 15^{\prime}$ S, $56^{\circ} 37^{\prime}$ W, 21.XII.1980, C.N. Cunha \& A. Prado 12129 (UEC).

22. Dalechampia schenckiana Pax \& Hoffm., Pflanzenr. IV. 147. XII (Heft 68): 49 1919. Neotype (designated by Webster \& Armbruster 1991): Brazil, Pernambuco, Garanhuns, G.L. Webster et al. 25648 (R!, isoneotype DAV). Figure 6d e 10d.

Dalechampia schenckiana has densely villous branches and 6-12 pistillate pinnatifid sepals. Morphologically, it is similar to D. leandri, what can be differentiated by aspects already mentioned above in the comments concerning that species.

Distribution, ecology, and conservation: $D$. schenckiana is endemic to Brazil (Flora do Brasil 2020, under construction) and is known only from the northeastern region of the country. In the study area, it is known from the states of Bahia, Pernambuco, Sergipe, and Alagoas. It is recorded here for the first time in Alagoas, occurring in the caatinga (stricto sensu) and rock outcrop vegetation. The species is designated, according to IUCN (2001) criteria, as of least concern (LC) due to its EOO of ca. 929, 920. $476 \mathrm{~km}^{2}$ and endangered (EN) due to its AOO of $104.000 \mathrm{~km}^{2}$. Some specimens were collected in protected areas in the study region and some of the collections analyzed came from the Morro do Chapéu State Park and the Raso do Catarina Ecological Station (both in Bahia), and the Catimbau National Park (Pernambuco).

Material examined: BRAZIL, ALAGOAS: Olho d'água do Casado, Capelinha, $9^{\circ} 25^{\prime} \mathrm{S}, 37^{\circ} 49^{\prime} \mathrm{W}$, 17.IX.2001. fl., fr., L.M. Cordeiro 484 (PEUFR). BAHIA: Feira de Santana, $12^{\circ} 13^{\prime}$ 'S, $38^{\circ} 57^{\prime} \mathrm{W}$, 22.XI.1986, fl., G.L. Webster 25846 (HUEFS). PERNAMBUCO: Buíque-Catimbau, $8^{\circ} 34^{\prime}$ 'S, $37^{\circ} 15^{\prime} \mathrm{W}, 25 . I V .2013$, R.A. Pereira-Silva 37 (PEUFR). SERGIPE: Canindé do São Francisco, Fazenda Poço Verde, 9`39'S, 37²7’W, 23.III.2000, fl., R.A. Silva \& D. Moura 1405 (PEUFR).

23. Dalechampia stipulacea Müll. Arg., Linnaea 34: 221. 1865. Holotype: Peru, without locality, R. Pavon s.n. (G!). Figure 6e \& 10e.

Dalechampia stipulacea stands out for having glandular stipitate trichomes on the margins of the leaf blade, staminate bracteole, and being the only species in the Northeast with parastipules at the base of the petiolar stipule. It resembles $D$. ficifolia by having 3-lobed leaves and bracts; they can be differentiated in the aspects commented in this latter species. Distribution, ecology, and conservation: $D$. stipulacea is found in South America growing in seasonal tropical and subtropical forest areas (Webster \& Armbruster 1991). In Brazil, it occurs in the central-western (Mato Grosso do Sul), southeastern (Minas Gerais, Rio de Janeiro and São Paulo), Southern (Paraná, Rio Grande do Sul and Santa Catarina), and northeastern regions (Flora do Brasil 2020, in constr.). In the study area, there have been records of its occurrence only in the states of Maranhão and Pernambuco in Atlantic Forest vegetation. D. stipulacea is designated, according to IUCN (2001) criteria, as least concern (LC) due to its EOO 10, 411, 504. $087 \mathrm{~km}^{2}$ and endangered (EN) due to its AOO of $632.000 \mathrm{~km}^{2}$.

Material examined: BRAZIL, PERNAMBUCO: Triunfo, 7.VI.1997, fl., fr., A.M. Miranda et al. 2695 (IPA). MARANHÃO: Buriti Bravo, Margem direita do Rio Itapecuru, 23.II.1983, fl., J.U. Santos et al. $684(\mathrm{~K})$. 
Additional material examined: BRAZIL, PARANÁ: Tuneiras do Oeste, Reserva Biológica das Perobas, estrada interna, $23^{\circ} 51^{\prime} \mathrm{S}$, 52 $45^{\prime}$ W, 27.X.2011, fl., M.G. Caxambu et al. 3615 (HCF); Goioerê, Parque Municipal Antônio Sestak, 249'S, 53ํ' 'W, 18.VIII.2007, fl., E.M. Silva s.n (HCF 5838). SÃO PAULO: Piracicaba, Mata da Pedreira, ESALQ/USP, 2242'S, 47³7'W, 27.IX.1985, fl., E.L.M. Catharine 432 (BHCB). MINAS GERAIS: Pedro Leopoldo, Lara Vermelha, 19³6'S, 44²'W, 15.VI.1978, fl., J.M. Ferrari 145 (BHCB); Juiz de Fora, $21^{\circ} 45^{\prime}$ S, $43^{\circ} 26^{\prime} \mathrm{W}, 02 . \mathrm{IX} .1981$, fl., TSMG 749 (BHCB). SANTA CATARINA: Siderópolis, Barragem do Rio São Bento, 28³6'S, 49³3’W, 05.XI.2009, fl., M. Verdi, A.L. Tomazi \& G. Klemz 3043 (FURB).

24. Dalechampia subintegra Müll. Arg., Flora Brasiliensis 11: 650. 1874. Holotype: Brazil, Bahia, without locality, Blanchet s.n. (G!). Figure 7a \& 10f.

Dalechampia subintegra shares 3-foliolate leaves, a slender stigma, and 3-lobed involucral bracts with $D$. peckoltiana, but its stylar column is thinner than that of $D$. peckoltiana. The species, however, still needs to be further investigated. Other morphological comparisons can be found in the comments presented above concerning $D$. peckoltiana.

Distribution, ecology, and conservation: $D$. subintegra is endemic to Brazil (Flora do Brasil 2020, under construction), being recorded only from the northeastern region of the country in the states of Bahia and Pernambuco. It is found here for the first time in the study area for Paraiba State. D. subintegra is included in the category of endangered because of its EOO of $0.000 \mathrm{~km}^{2}$ and as endangered (CR) due to its AOO of $8.000 \mathrm{~km}^{2}$.

Material examined: BRAZIL, PARAÍBA: Areia, $6^{\circ} 57^{\prime} \mathrm{S}, 35^{\circ} 42^{\prime} \mathrm{W}$, 15.VII.1976, P.C. Fevereiro 170 (RB).

25. Dalechampia sylvestris S. Moore, Trans. Linn. Soc. London, 2: 467-468. 1895. Holotype: Brazil Mato Grosso, between Santa Cruz and Tapirapuã 376 (BM!). Figure $6 \mathrm{f} \& 10 \mathrm{~g}$.

Apparently, Dalechampia sylvestris seems morphologically with D. peckoltiana due the leaves 3-foliolate and involucral bracts deeply 3-lobed. However, they are differentiated in the comments of this last species. The taxon is referred to the northeast and Central region in the states of Bahia, Mato Grosso, Minas Gerais. Dalechampia sylvestris is included in the category of Least Concern species because an EOO of the $855,412.426 \mathrm{~km}^{2}$ and as endangered (EN) due to an AOO of the $56.000 \mathrm{~km}^{2}$.

Material examined: BRAZIL, BAHIA: Macugê, $13^{\circ}, 7^{\prime}, 3^{\prime \prime} \mathrm{S}, 41^{\circ}$, 29',13” W, 20.II.2002, A. M. Giulietti, \& R. M. Harley 2055 (HUEFS). CEARÁ: Parque Nacional do Araripe, Crato, 19.I.1983, T. Plowman 12736 (EAC). MINAS GERAIS: without locality, 01.I.1816, SaintHilaire $1062(\mathrm{P})$.

26. Dalechampia tiliifolia Lam. Encycl., 2: 257.1786. Holotype: possibly Peru, without locality, Herb. Jussieu (P). Figure 7b \& $10 \mathrm{~h}$.

Dalechampia tiliifolia is easily recognized by having leaves varying from entire to lobed, linear bracteal stipules, involucral bracts entire to slightly 3-lobed, chartaceous, with 7-9 primary veins, and stigma discoid to peltate.

Distribution, ecology, and conservation: D. tiliifolia is widely distributed in South America (Webster \& Armbruster 1991), and has been recorded in the northern (Acre, Amazonas, Amapá, Pará, Rondônia and Roraima), central-western (Goiás and Mato Grosso), and northeastern regions of Brazil (Flora do Brasil 2020, under construction). In the study area, it has been collected in Bahia, Ceará, Maranhão, Pernambuco, Piauí, and Sergipe in cerrado and Atlantic Forest vegetation. The species is included in the category of least concern because of its EOO of ca. $16,304,443.697 \mathrm{~km}^{2}$ and as endangered (VU) due to its AOO of 1, $264.000 \mathrm{~km}^{2}$. None of the collections come from protected areas, but specimens may yet be found in protected areas within the extent of occurrence of the species such as the Chapada Diamantina National Park and Morro do Chapéu State Park (Bahia), Serra das Confusões National Park and Serra da Capivara National Park (Piauí), AraripeApodi National Forest (Ceará), Catimbau National Park (Pernambuco), and Chapada das Mesas National Park (Maranhão).

Material examined: BRAZIL, BAHIA: Entre Rios, Areial, $12^{\circ} 12^{\prime}$ S, 37 $57^{\prime}$ W, 13.IV.2012, A.V. Popovkin 1094 (HUEFS). CEARÁ: Ubajara, Parna do Ubajara, 0351'S, 4055'W, 13.IX.1982, fl., A. Fernandes \& P. Gibbs s.n. (EAC 15081). MARANHÃO: Loreto, Ilha de Balsas, $7^{\circ} 28^{\prime}$ 'S, $45^{\circ} 3^{\prime}$ W, 17.II.1970, fl., G. Eiten \& L.T. Eiten 10657 (K). PERNAMBUCO: Recife, 8³'S, 3452'W, 30.V.1971, fl., E.P. Heringer et al. 1005 (IPA). PIAUÍ: Tamboril, 08²4'S, 42 ${ }^{\circ} 54^{\prime} \mathrm{W}$, 22.VII.1979, fr., F. Chagas \& Silva 17 (K). SERGIPE: Siriri, Mata do Cipó, $10^{\circ} 35^{\prime}$ 'S $37^{\circ} 08^{\prime}$ W, 28.VIII.2013, fl., J.P. Santana et al. 206 (ASE).

Additional material examined: BRAZIL. TOCANTINS: Itacajá, $35 \mathrm{~km}$ após a aldeia Pedra Branca, $8^{\circ} 37^{\prime} \mathrm{S}, 4^{\circ} 31^{\prime} \mathrm{W}, 07 . \mathrm{V} .2000$, fl., A.A. Santos et al. 686 (CEN). RONDÔNIA: Pimenta Bueno, 11³9'S, $61^{\circ} 11^{\prime}$ W, 25.V.1990, fl., fr., L.A. Skorupa et al. 798 (CEN). RORAIMA: Boa Vista, Fazenda Quixabeira, 2²9’N, 6040’W, 15.VIII.1977, fl., L. Coradin \& M.R. Cordeiro s.n. (INPA 683). GOIÁS: Guarani, Fazenda Forquilha, 05.III.2001, fl., fr., M.L. Fonseca et al 2418 (IBGE).

27. Dalechampia triphylla Lam., Encycl. 2: 258. 1786. Holotype: Brazil, without locality, J. Dombey s.n. (P!, isotype NY). Figure 7c $\& 10 \mathrm{i}$.

In the vegetative stage, Dalechampia triphylla can be quite easily confused with other species with 3-foliolate leaves. It is characterized, however, by its hispid fruits with pistillate sepals widely pinnatifid in fruits

Distribution, ecology, and conservation: $D$. triphylla is reported from Mexico and Brazil. It has been reported from the northern (Pará), southeastern (Espírito Santo, Minas Gerais, Rio de Janeiro and São Paulo), and northeastern region of Brazil (Flora do Brasil 2020, under construction). In the northeastern region, the species has been recorded from Pernambuco State in Atlantic Forest environments. Dalechampia triphylla is designated, according to IUCN (2001) criteria, as of least concern (LC) due to its EOO of ca. 13, 041, 354. $454 \mathrm{~km}^{2}$, and endangered (EN) due to its AOO of $292.000 \mathrm{~km}^{2}$.

Material examined: BRAZIL, PERNAMBUCO: Maraial, $8^{\circ} 48^{\prime}$ 'S, $35^{\circ} 45^{\prime} \mathrm{W}, 13$. III.1994, A.M. Miranda et al. 8253 (HST).

Additional examined material: BRAZIL, SÃO PAULO: Bom Sucesso de Itararé, $24^{\circ} 19^{\prime}$ S, $49^{\circ} 08^{\prime}$ W, 19.VIII.1995, fl., V.C. Souza et al. 8891 (ESA); Apiaí, Estrada do Pinhalzinho, 24³0'S, 4850’W, 13.VII.1997, fl., fr., F. Chung et al. 96 (ESA). 
28. Dalechampia viridissima Webster, Brittonia 41:6. 1989. Holotype: Brazil, Bahia, CEPLAC grounds, G.L. Webster \& S. Armbruster 25165 (CEPEC!, isotypes DAV, GH, MO, NY, R. SP, UEC). Figure $7 \mathrm{~d} \& 10 \mathrm{j}$.

Dalechampia viridissima is characterized by reduced pubescence, linear bracteal stipules, and an intense green color of the involucral bracts, beyond this the pistillate sepals are $6-7$, minutely glandular at tip. This set of characters allows differentiate this species from other with 3-lobed leaves.

Distribution, ecology, and conservation: $D$. viridissima is endemic to Brazil (Webster \& Armbruster) with records of occurrence in the southeast (Espírito Santo), and northeastern regions (Bahia) of the country, being found in ombrophilous forest environments. This species is included in the critically endangered category because of its AOO of $4,000 \mathrm{~km}^{2}$

Material examined: BRAZIL, BAHIA: Jussari, $15^{\circ} 7^{\prime}$ 'S, 39³0'W, 13.VIII.1998, fl., A.M. Amorim et al. 2466 (NY).

\section{Author Contributions}

Rafaela Alves Pereira-Silva: conceived the idea and structured the manuscript; contributed to the writing of the text, and the interpretation of the results.

Beatriz Rayrana de Araújo Gama: contributed with the descriptions of the species.

Sarah Maria Athiê-Souza: contributed to the writing of the text, and the interpretation of the results.

André Laurênio de Melo: contributed to the writing of the text, and the interpretation of the results.

Margareth Ferreira de Sales: designed the study and has contributed to the correction and discussion of the results, and to research funding.

\section{Acknowledgements}

The authors thank the Coordenação de Aperfeiçoamento de Pessoal de Nível Superior (CAPES) for providing the grant for the first author, including the fellowship to Kew Gardens herbarium; the PROTAX Project (CNPq 440459/2015-0) named "Filogenia, diversidade e distribuição geográfica de Euphorbiaceae, com ênfase em Hippomaneae, Manihoteae e Plukenetieae", for providing the grants for the second author. We also thank the herbaria curators, Regina Carvalho and Melquíades Henrique Silva Barbosa, for the making of the illustration and for the making colored illustration.

\section{Conflicts of Interest}

We, the authors, declare that we have no conflicts of interests related to the publication of this manuscript.

\section{References}

ALLEM, A. C \& WAECHTER, J.L. 1977. Notas Sistemáticas y Nuevos Sinónimos en Euphorbiaceae de América Del Sur-II. Rev. Brasil. Biol., 37 (1): 91-101.

ALVES, M. V. 1998. Checklist das espécies de Euphorbiaceae Juss. ocorrentes no semiárido pernambucano, Brasil. Acta Bot. Bras. 12: 485-495.
ARMBRUSTER, W.S. \& WEBSTER, G.L. 1979. Pollínation of two species of Dalechampia (Euphorbiaceae) in Mexico by Euglossine bees. Biotrop. $11: 278-283$

ARMBRUSTER, W.S. \& WEBSTER, G.L. 1982. Divergent pollination system in sympatric species of South American Dalechampia (Euphorbiaceae). Am Midl Nat. 108(2): 325-337.

ARMBRUSTER, W.S. 1993. Evolution of plant pollination systems: hypotheses and tests

with the neotropical vine Dalechampia. Evol. 47(5): 1480-1505.

ARMBRUSTER, W.S. 1994. Early evolution of Dalechampia (Euphorbiaceae): Insights from phylogeny, biogeography, and comparative ecology. Ann. Miss. Bot. Gard. 81: 302-316.

ARMBRUSTER, W.S. 2017. Euphorbiaceae. Dalechampia. FNA, 12. http:// www.efloras.org/florataxon.aspx?flora id=1\&taxon id=109241 (last access on $16 / 12 / 2019$ )

BACHMAN, S., MOAT, J., HILL, A.W., DE LA TORRE, J., SCOTT, B. 2011. Supporting red List threat assessments with GeoCAT: geospatial conservation assessment tool. ZooKeys, 150: 117-126.

BARBOSA, M.R.V., SOTHERS, C., MAYO, S., GAMARRA-ROJAS C. \& MESQUITA A.C. 2006. Checklist das Plantas do Nordeste Brasileiro: Angiospermas e Gymnospermas. Ministério da Ciência e Tecnologia. 156 pp.

CUNHA, T.J.F., PETRERE, V.G., SILVA, D.J., MENDES, A.M.S., MELO, R.F., NETO, M.B.O., SILVA, M.S.L. \& ALVAREZ, I.A. 2010. Principais solos do semiárido tropical brasileiro: caracterização, potencialidades, limitações, fertilidade e manejo. In Semiárido brasileiro: pesquisa, desenvolvimento e inovação (SILVA, P.C.G., ed). Petrolina: Embrapa Semiárido, 50-87.

EMBRAPA. Centro de Pesquisa Agropecuária do Trópico Semi-Árido (PetrolinaPE). 1993. Relatório técnico do Centro de Pesquisa Agropecuária do Trópico Semi-Árido - CPATSA 1979-1990. Petrolina, PE. 175 pp.

Flora do Brasil 2020 under construction. Jardim Botânico do Rio de Janeiro. Available from: http://floradobrasil.jbrj.gov.br/ (last access 16 August 2018).

Hickman, E. J., Yates, C. J. \& Hopper, S. D. 2017. Botanical illustration and photography: a southern hemisphere perspective. Aust. Syst. Bot. 30 291-325.

IBGE. Instituto Brasileiro de Geografia e Estatística. 2004. Mapa de vegetação do Brasil. 3.ed. Rio de Janeiro, Ministério do Planejamento, Orçamento e Gestão.

IUCN. International Union for Conservation of Nature. 2001. IUCN red list categories and criteria: version 3.1. Gland: IUCN Species Survival Commission.

KUR, A. 2018. On the maintained significance of botanical illustration in modern plant identification guides. Doctoral thesis, The University of Tennessee at Chattanooga, USA.

MAYA-LASTRA, C.A., SECCO, R., SALES M.F. \& SILVA, R.A.P. 2015. Dalechampia. In Lista de Espécies da Flora do Brasil. Rio de Janeiro: Jardim Botânico do Rio de Janeiro. http://floradobrasil. jbrj.gov.br/jabot/ floradobrasil/FB17549 (last access 18 August 2018).

MORI, A.S, SILVA, L.A.M., LISBOA, G. \& CORANDIN, L. 1989. Manual de Manejo do Herbário Fanerogâmico. Centro de Pesquisas do Cacau, Ilhéus. $103 \mathrm{pp}$.

PAX, F. \& HOFFMAN, K. 1919. Euphorbiaceae-Dalechampieae. In Das Pflanzenreich. Regni vegetabilis conspectus (A. Engler, ed.), Leipzig, 147 XII (helf 68): 1-56.

PEREIRA-SILVA, R.A. 2015. Dalechampia L. (Euphorbiaceae, Acalyphoideae) em Pernambuco. M.S. thesis. Recife: Universidade Federal Rural de Pernambuco.

PEREIRA-SILVA, R.A., ATHIÊ-SOUZA, S.M., SECCO, R.S., MELO, A.L. \& SALES, M.F. 2016. Dalechampia erythrostyla (Euphorbiaceae), a New Species from Northeastern Brazil. Syst. Bot. 41: 989-995.

PEREIRA-SILVA, R.A., ATHIÊ-SOUZA, S.M., ARMBRUSTER, W.S., MELO, A.L. \& SALES, M.F. 2018. Typification and reestablishment of the Linnaean name Dalechampia colorata (Euphorbiaceae). Taxon 67(1): 186-190.

QUEIROZ, L.P. 2009. Legumes of the Caatinga. Royal Botanic Garden Edinburgh, UK. 443 pp. 
RADFORD A.E., DICKISON, W.C. \& MASSEY, J.R. 1974. Vascular plant systematic. Harper \& Row Publishers, New York, 891 pp.

RODRIGUES, A.S. 2007. As tribos Dalechampieae Müll. Arg. e Manihoteae Melchior (Euphorbiaceae) no Distrito Federal, Brasil. M.S. thesis. Distrito Federal.

SALES, M.F., MAYO, S.J., \& RODAL, M.J.N. 1998. Plantas vasculares das florestas serranas de Pernambuco: Um checklist da flora ameaçada dos brejos de altitude, Pernambuco, Brasil. Recife: Universidade Federal Rural de Pernambuco.

SÁTIRO, L.N. \& ROQUE, N.A. 2008. Família Euphorbiaceae nas caatingas arenosas do médio Rio São Francisco, BA, Brasil. Acta Bot. Bras. 1:99-118.

THIERS, B. 2017. [continuously updated]. Index Herbariorum: A global directory of public herbaria and associated staff. New York Botanical Garden's Virtual Herbarium. http://sweetgum.nybg.org/science/ih/.

WEBSTER, G. L. 1989. Three New Species of Dalechampia (Euphorbiaceae) from Brazil. Brittonia 41: 1-6.
WEBSTER, G.L. \& ARMBRUSTER, W.S. 1991. A synopsis of the neotropical species of Dalechampia (Euphorbiaceae). Bot. J. Lin. Soc. 105: 137-177.

WEBSTER G.L. 2014. Euphorbiaceae. In Flowering Plants. Eudicots. The Families and Genera of Vascular Plants (K. Kubitzki, ed). Springer, Berlin, Heidelberg, v. 11.

WORLD CHECKLIST OF SELECTED PLANT FAMILIES (WCSP). Disponível em: <http://wcsp.science.kew.org/home.do>. Acesso em 20 junho 2018.

Received: 02/09/2019

Revised: 04/03/2020

Accepted: $17 / 04 / 2020$

Published online: 12/06/2020 